\title{
Solution mechanisms of phosphorus in quenched hydrous and anhydrous granitic glass as a function of peraluminosity
}

\author{
B. O. Mysen, ${ }^{1}$ F. Holtz, ${ }^{2 \cdot *}$ M. Pichavant, ${ }^{2}$ J.-M. Beny, ${ }^{2}$ and J.-M. Montel ${ }^{3}$ \\ 'Geophysical Laboratory and Center for High Pressure Research, Carnegie Instn. Washington, 5251 Broad Branch Rd., NW.. \\ Washington, DC 20015, USA \\ 2CRSCM-CNRS, 1a, rue de la Ferollerie, 45071 Orleans, France \\ ${ }^{3}$ Department de Geologie, URA 10 du CNRS, Universite Blaise Pascal, 5, rue Kessler, 63038 Clermont-Ferrand, France
}

(Received June 21, 1996; accepted in revised form May 16, 1997)

\begin{abstract}
Solution mechanisms of $\mathrm{P}$ in metaluminous to peraluminous quenched, hydrous ( $\sim 9 \mathrm{wt} \%$ $\mathrm{H}_{2} \mathrm{O}$ ) and anhydrous glasses in the system $\mathrm{CaO}-\mathrm{Na}_{2} \mathrm{O}-\mathrm{K}_{2} \mathrm{O}-\mathrm{Al}_{2} \mathrm{O}_{3}-\mathrm{SiO}_{2}-\mathrm{P}_{2} \mathrm{O}_{5}$ have been examined with microRaman spectroscopy. The principal aim was to examine relative stability of phosphate complexes as a function of bulk chemical composition. Increasing peraluminosity was accomplished by increasing $\mathrm{Al}^{3+}$ and $\mathrm{Ca}^{2+}$ proportions with constant $\mathrm{SiO}_{2}$ content. The molar ratio $\mathrm{Al}_{2} \mathrm{O}_{3} /\left(\mathrm{CaO}+\mathrm{Na}_{2} \mathrm{O}+\mathrm{K}_{2} \mathrm{O}\right)(\mathrm{A} /$ $\mathrm{CNK}$ ) ranged from 1 (metaluminous) to $\sim 1.3$ (peraluminous).

In all compositions $\mathrm{P}^{5+}$ is bonded to $\mathrm{Al}^{3+}$ to form $\mathrm{AlPO}_{4}$ complexes. The principal solution mechanism is one where depolymerized species $\left(\mathrm{Q}^{3}\right)$, involving $\mathrm{Al}^{3+}$ both within and outside the aluminosilicate network, interact with $\mathrm{P}$ to form the $\mathrm{AlPO}_{4}$ complex together with $\mathrm{Q}^{4}$ species. The mechanism does not involve alkali metals or alkaline earths. In anhydrous compositions, the spectra are interpreted to suggest $\mathrm{Si}-\mathrm{O}-\mathrm{P}$ cross-linking in the structure. In hydrous compositions, evidence for Si-O-P bonding is less evident. In such glasses, there is, however, possible spectroscopic evidence for Si-OH bonding and possibly $\mathrm{P}-\mathrm{OH}$ bonding resulting from breakage of cross-linking Si-O-P bonds existing in the anhydrous glasses. Therefore, the water content of peraluminous aluminosilicate melts is likely to affect the solubility behavior of $\mathrm{P}$, and conversely, the solubility behavior of $\mathrm{H}_{2} \mathrm{O}$ is affected by $\mathrm{P}$ in such melts. Copyright c) 1997 Elsevier Science Ltd
\end{abstract}

\section{INTRODUCTION}

The geochemical behavior of phosphorus in both mafic and silicic magmas is receiving increasingly detailed attention (e.g., Ryerson and Hess, 1980; Watson and Capobianco, 1981; Harrison and Watson, 1984; Pichavant et al., 1992; Toplis et al., 1994a,b; Wolf and London, 1994). Although generally present in comparatively low concentrations in natural magmas (less than 2-3 wt $\% \mathrm{P}_{2} \mathrm{O}_{5}$ ), even in this abundance range $P$ strongly modifies both physical and chemical properties of silicate liquids (Wyllie and Tuttle, 1964; Kushiro, 1975; Watson, 1976; Visser and Koster Van Groos, 1979; Ryerson and Hess, 1980; London, 1987; Dingwell et al., 1993; London et al., 1993; Toplis et al., 1994a; Toplis and Dingwell, 1996).

In silicic magmas, the $\mathbf{P}$ concentration generally is buffered by the solubility of apatite. Early studies (Ryerson and Hess, 1980; Watson and Capobianco, 1981; Harrison and Watson, 1984) have determined that apatite solubility in felsic melts is dependent primarily on temperature and melt $\mathrm{SiO}_{2}$ content and generally is small for crustal temperatures and melt compositions (e.g., $0.02 \mathrm{wt} \% \mathrm{P}_{2} \mathrm{O}_{5}$ for a melt having $75 \mathrm{wt} \% \mathrm{SiO}_{2}$ at $800^{\circ} \mathrm{C}$, Harrison and Watson, 1984). Recent studies, however, have revealed that apatite solubility depends in a complex way on other melt compositional parameters such as the balance between $\mathrm{AI}$ and alkali plus

*Present address: Inst. Mineralogie, Univ. Hannover, Welfengarten 1, D-30167 Hannover, Germany.
$\mathrm{Ca}$ (i.e., $\mathrm{A} / \mathrm{CNK}=\mathrm{Al}_{2} \mathrm{O}_{3} /\left(\mathrm{CaO}+\mathrm{Na}_{2} \mathrm{O}+\mathrm{K}_{2} \mathrm{O}\right)$, molar (Pichavant et al., 1992; Richard et al., 1992: Wolf and London, 1994), and $\mathrm{FeO} / \mathrm{Fe}_{2} \mathrm{O}_{3}$ ratio (Richard et al., 1992). For constant melt $\mathrm{SiO}_{2}$ content and temperature, apatite solubility is increased dramatically for peraluminous liquids ( $\mathrm{A} / \mathrm{CNK}$ $>1$ ). Solubilities of up to several wt $\% \mathrm{P}_{2} \mathrm{O}_{5}$ for peraluminous silicic liquids in equilibrium with apatite at 750 $1000^{\circ} \mathrm{C}$ have been reported (Pichavant et al., 1992; Richard et al., 1992; Wolf and London, 1994). To be interpreted, such results require a better understanding of the structural role of $P$ with the aid of detailed structural studies of multicomponent P-bearing aluminosilicate melt compositions.

Most P-bearing silicate melt compositions studied in the glass literature are peralkaline, i.e., molar contents of alkali greatly exceeds that of $\mathrm{Al}(\mathrm{A} / \mathrm{CNK}<1)$. For such compositions, results of spectroscopic studies have shown that the addition of $\mathrm{P}$ increases polymerization of silicate network. In those melts alkali metals associate with $\mathrm{P}$ to form phosphate complexes and the number of nonbridging oxygens decreases (Nelson and Tallant, 1984; Dupree et al., 1988, 1989 ). In contrast, for both subaluminous $(\mathrm{A} / \mathrm{CNK}=1$ ) and peraluminous $(\mathrm{A} / \mathrm{CNK}>1)$ melts, it has been suggested that $\mathrm{P}$ speciation is characterized by the presence of $\mathrm{AlPO}_{4}$-like units (Mysen et al., 1981; Kosinski et al., 1988; Dupree et al., 1989; Gan and Hess, 1992). Complexing of $\mathrm{P}^{5+}$ with $\mathrm{Al}^{3+}$ in peraluminous aluminosilicate melts would account for the strong increase of apatite solubility found experimentally (Pichavant et al., 1992; Wolf and London, 1994). However, none of the different spectroscopic studies 
Table 1. Composition of the glasses.

\begin{tabular}{|c|c|c|c|c|c|c|c|c|c|c|c|c|}
\hline & \multicolumn{3}{|c|}{244} & \multicolumn{3}{|c|}{245} & \multicolumn{3}{|c|}{246} & \multicolumn{3}{|c|}{247} \\
\hline & nom & wet & dry & nom & wet & dry & nom & wet & dry & nom & wet & dry \\
\hline $\mathrm{SiO}_{2}$ & 75.00 & 69.06 & 75.97 & 75.00 & 68.54 & 75.79 & 75.00 & 65.79 & 74.89 & 75.00 & 69.32 & 75.50 \\
\hline $\mathrm{Al}_{2} \mathrm{O}_{3}$ & 14.10 & 12.62 & 13.88 & 14.40 & 12.85 & 14.21 & 14.70 & 12.72 & 14.48 & 14.80 & 13.96 & 15.11 \\
\hline $\mathrm{CaO}$ & 0.21 & 0.19 & 0.21 & 1.47 & 1.32 & 1.46 & 2.73 & 2.55 & 2.90 & 4.00 & 3.07 & 3.32 \\
\hline $\mathrm{Na}, \mathrm{O}$ & 4.18 & 3.56 & 3.92 & 3.18 & 2.68 & 2.96 & 2.20 & 1.92 & 2.19 & 1.26 & 1.50 & 1.62 \\
\hline $\mathrm{K}_{2} \mathrm{O}$ & 6.35 & 5.35 & 5.89 & 4.83 & 4.04 & 4.47 & 3.30 & 2.88 & 3.28 & 1.91 & 2.16 & 2.3 \\
\hline $\mathrm{P}_{2} \mathrm{O}_{5}$ & 0.16 & 0.12 & 0.13 & 0.12 & 1.00 & 1.11 & 2.07 & 1.99 & 2.27 & 3.03 & 2.36 & 2.55 \\
\hline Total & 100.00 & 90.90 & 100.00 & 100.00 & 90.43 & 100.00 & 100.00 & 87.85 & 100.00 & 100.00 & 92.37 & 100.00 \\
\hline $\mathrm{A} / \mathrm{CKN}^{*}$ & 1.01 & 1.07 & 1.07 & 1.22 & 1.29 & 1.29 & 1.51 & 1.48 & 1.48 & 1.91 & 1.84 & 1.84 \\
\hline $\mathrm{Na} / \mathrm{K}^{* *}$ & 1.00 & 1.01 & 1.01 & 1.00 & 1.10 & 1.01 & 1.00 & 1.01 & 1.01 & 1.00 & 1.06 & 1.06 \\
\hline \multirow[t]{3}{*}{$\mathrm{Ca} / \mathrm{P}^{* *}$} & 1.66 & 2.00 & 2.00 & 1.66 & 1.67 & 1.67 & 1.67 & 1.62 & 1.62 & 1.67 & 1.65 & 1.65 \\
\hline & \multicolumn{3}{|c|}{248} & \multicolumn{3}{|c|}{249} & \multicolumn{3}{|c|}{250} & \multicolumn{3}{|c|}{251} \\
\hline & nom & wet & dry & nom & wet & dry & nom & wet & dry & nom & wet & dry \\
\hline $\mathrm{SiO}_{2}$ & 75.00 & 67.75 & 75.69 & 75.00 & 68.03 & 75.92 & 75.00 & 68.96 & 75.56 & 75.00 & 67.92 & 75.48 \\
\hline $\mathrm{Al}_{2} \mathrm{O}_{3}$ & 14.10 & 12.47 & 13.93 & 14.30 & 12.58 & 14.04 & 14.40 & 12.83 & 14.06 & 14.40 & 12.88 & 14.31 \\
\hline $\mathrm{CaO}$ & 0.12 & 0.08 & 0.09 & 0.88 & 0.79 & 0.88 & 1.64 & 1.49 & 1.63 & 2.40 & 2.10 & 2.33 \\
\hline $\mathrm{Na}_{2} \mathrm{O}$ & 4.21 & 3.51 & 3.92 & 3.46 & 2.83 & 3.16 & 2.74 & 2.41 & 2.64 & 2.05 & 1.79 & 1.99 \\
\hline $\mathrm{K}_{2} \mathrm{O}$ & 6.41 & 5.57 & 6.22 & 5.24 & 4.41 & 4.92 & 4.16 & 3.54 & 3.88 & 3.11 & 2.73 & 3.03 \\
\hline $\mathrm{P}_{2} \mathrm{O}_{5}$ & 0.16 & 0.13 & 0.15 & 0.12 & 0.97 & 1.08 & 2.06 & 2.04 & 2.24 & 3.04 & 2.57 & 2.86 \\
\hline Total & 100.00 & 89.51 & 100.00 & 100.00 & 89.61 & 100.00 & 100.00 & 91.27 & 100.00 & 100.00 & 89.99 & 100.00 \\
\hline $\mathrm{A} / \mathrm{CKN}^{*}$ & 1.01 & 1.05 & 1.05 & 1.17 & 1.24 & 1.24 & 1.37 & 1.40 & 1.40 & 1.61 & 1.65 & 1.65 \\
\hline $\mathrm{Na} / \mathrm{K}^{* *}$ & 1.00 & 0.96 & 0.96 & 1.00 & 0.98 & 0.98 & 1.00 & 1.03 & 1.03 & 1.00 & 1.00 & 1.00 \\
\hline $\mathrm{Ca} / \mathrm{P}^{* *} *$ & 0.95 & 0.78 & 0.78 & 0.99 & 1.03 & 1.03 & 1.00 & 0.92 & 0.92 & 1.00 & 1.03 & 1.03 \\
\hline
\end{tabular}

* Molar ratio, $\mathrm{Al}_{2} \mathrm{O}_{3} /\left(\mathrm{CaO}+\mathrm{Na}_{2} \mathrm{O}+\mathrm{K}_{2} \mathrm{O}\right) * *$ Atomic ratios

so far available have been conducted on compositions approaching either natural peraluminous or experimental melts showing elevated apatite solubility.

Here, we present room temperature Raman spectroscopic data on the mechanisms of solution of $\mathrm{P}_{2} \mathrm{O}_{5}$ in peraluminous quenched melts (glass) in the system $\mathrm{SiO}_{2}-\mathrm{Al}_{2} \mathrm{O}_{3}-\mathrm{Na}_{2} \mathrm{O}$ $\mathrm{K}_{2} \mathrm{O}-\mathrm{CaO}-\mathrm{P}_{2} \mathrm{O}_{5}$ with and without $\mathrm{H}_{2} \mathrm{O}$. The data concern two series of glasses, one with a $\mathrm{Ca} / \mathrm{P}$ ratio of $5 / 3$ (i.e., same as in apatite) and the other with $\mathrm{Ca} / \mathrm{P}=1$, thus enabling to test the possible preference of $\mathrm{P}$ to coordinate with $\mathrm{Ca}$ rather than with Al.

\section{EXPERIMENTAL AND ANALYTICAL METHODS}

\subsection{Preparation of Glasses}

Starting materials were $\mathrm{P}_{2} \mathrm{O}_{5}$-free gels (or glasses). Nominally, these have constant $\mathrm{SiO}_{2}$ content of $75 \mathrm{wt} \%$ and constant $\mathrm{Na} / \mathrm{K}$ of 1. In each series of four compositions $(1: \mathrm{Ca} / \mathrm{P}=5 / 3$ and 2 : $\mathrm{Ca} /$ $\mathrm{P}=1$ ), $\mathrm{Al}$ and $\mathrm{Ca}$ progressively increase (along with $\mathrm{P}$ concentration), whereas the total alkali contents decrease, resulting in compositions becoming progressively more peraluminous $(\mathrm{A} / \mathrm{CNK}=1.0$, $1.1,1.2,1.3$, Table 1). There is, therefore, a positive correlation between A/CNK and phosphorus content of the two series of glasses (Fig. 1).

The glasses were initially synthesized hydrous at high pressure and temperature. The source of $\mathrm{P}_{2} \mathrm{O}_{5}$ was an $\mathrm{H}_{3} \mathrm{PO}_{4}$ solution. The gels were loaded in Pt capsules, together with the $\mathrm{H}_{3} \mathrm{PO}_{4}$ solution and a small additional amount of demineralized doubly-distilled water added so that glasses contain $9-10 \mathrm{wt} \% \mathrm{H}_{2} \mathrm{O}$. Two batches of eight hydrous glasses (about $200 \mathrm{mg}$ each) were synthesized in internally-heated pressure vessels, respectively, at $1100^{\circ} \mathrm{C}, 8 \mathrm{kbar}$ for 7-9 days ( see description of apparatus by Vielzeuf and Montel, 1994), and $1300^{\circ} \mathrm{C}, 4 \mathrm{kbar}$ for 3 days (see Roux et al., 1994, for description of apparatus).* The samples were contained in sealed Pt containers.

All glasses were analyzed with a Cameca SX 50 electron microprobe to check for their composition and chemical homogeneity. Analytical conditions and standards were those established previously for $\mathrm{P}_{2} \mathrm{O}_{5}$-bearing glasses of similar compositions (Pichavant et al., 1992) using the precautions described by Pichavant (1987) for analysis of hydrous alkali aluminosilicate glasses. Results are given in Table 1 and recalculated to $100 \%$ to compare with nominal compositions. Macusani glass was used as $\mathrm{P}_{2} \mathrm{O}_{5}$ standard. The water contents of two of the glasses, 245 and 248, were determined with Karl Fischer titration (Behrens, 1995; Holtz et al., 1995). The analyzed values ( 8.53 and $8.27 \mathrm{wt} \% \mathrm{H}_{2} \mathrm{O}$, respectively) compare well with the maximum water contents from the proportions of the reactants $(8.9-9.1 \mathrm{wt} \%)$.

The Raman microspectroscopic analyses of the dry compositions were performed from small chips of hydrous glasses that were slowly dehydrated in situ in a Pt wire furnace of the type developed by Mysen and Frantz (1992) for high-temperature, in situ microRaman spectroscopy. Complete dehydration was taken as that where there was no longer Raman intensity near $3600 \mathrm{~cm}^{-1}$ (OH stretching) corresponding to less than $0.1 \mathrm{wt} \% \mathrm{H}_{2} \mathrm{O}$ in the glass (B. O. Mysen and D. Virgo, unpubl. data). The Raman analyses of hydrous glasses were carried out on small glass chips.

Raman spectra were recorded with a Dilor XY confocal microRaman spectrometer equipped with a cryogenic Wright Model CCD

* All samples except no. 246 were prepared at $1100^{\circ} \mathrm{C}$ and $8 \mathrm{kbar}$. Sample 246 was prepared at $1300^{\circ} \mathrm{C}$ and $4 \mathrm{kbar}$. 


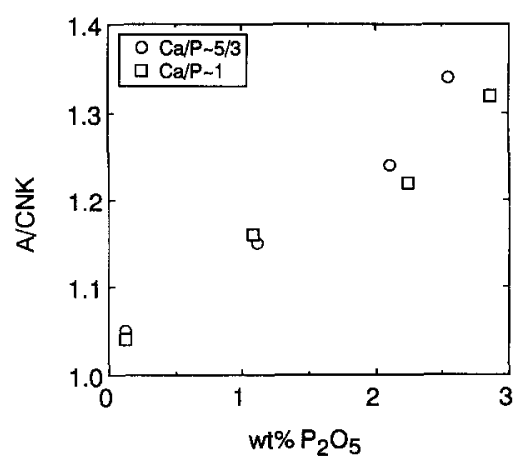

Fig. 1. Relationship between peraluminisity $(\mathrm{A} / \mathrm{CNK})$ and $\mathrm{P}_{2} \mathrm{O}_{5}$ content of the glasses.

05-11-0-202 charge-coupled detector (CCD). The excitation source was the $514 \mathrm{~nm}$ line of a Coherent Innova Model 90-5 $\mathrm{Ar}^{+}$laser operating at several hundred $\mathrm{mW}$ at the sample. Integration times ranged from 60 to $300 \mathrm{~s}$. The spectra were recorded in the frequency ranges $200-1800 \mathrm{~cm}^{-1}$ and $3000-4000 \mathrm{~cm}^{-1}$.

The high-frequency portion of the spectra was deconvoluted with lines of Gaussian shape as is normally done with Raman spectra of silicate glasses (See Mysen, 1992, for detailed discussion). Prior to deconvolution of the spectra, the instrumental background was subtracted by using a line obtained by least-square fitting of the data points at frequencies where no Raman scattering was observed. The spectra were then corrected for temperature- and frequency-dependent scattering intensity (Long, 1977) and the intensities were normalized to the absolute maximum intensity. The curve-fitting is based on the minimization of the squares of the deviations between the observed and calculated Raman envelopes using the algorithm described by Davidon (1966) (see also Seifert et al., 1982; Mysen et al., 1982; Mysen, 1992, for details). The line parameters were treated as independent variables. The number of lines was determined statistically to be that number where additional lines did not improve the quality of the fit significantly. A significant shift in $x^{2}$ corresponds to a $10 \%$ or more improvement when increasing the number of independent variables by (Hamilton, 1965). As three independent variables are needed to describe one line, a $10 \% \mathrm{im}-$ provement in $\chi^{2}$ is required to justify an increase in the number of fitted lines by one.

\section{RESULTS}

The Raman spectra can be divided into two frequency regions. The low-frequency region between 200 and 1300 $\mathrm{cm}^{-1}$ contains the first order Raman bands associated with the aluminosilicate network (see Fig. 2 for examples). That between 3000 and $4000 \mathrm{~cm}^{-1}$ contains the $\mathrm{O}-\mathrm{H}$ stretch vibrations from hydroxyl groups and molecular $\mathrm{H}_{2} \mathrm{O}$ in samples containing dissolved $\mathrm{H}_{2} \mathrm{O}$ (Fig. 3). The presence of molecular $\mathrm{H}_{2} \mathrm{O}$ in the glass samples is evidenced by the weak band near $1600 \mathrm{~cm}^{-1}$ assigned $\mathrm{H}-\mathrm{O}-\mathrm{H}$ bending.

\subsection{Low-Frequency Region $\left(200-1300 \mathrm{~cm}^{-1}\right)$}

The Raman spectra of anhydrous glasses (e.g., Fig. 2) overall show similar topology with a broad band centered near $1100 \mathrm{~cm}^{-1}$. This maximum is asymmetric toward lower frequency. There is another strong maximum near $500 \mathrm{~cm}^{-1}$ with additional spectral detail near $600 \mathrm{~cm}^{-1}$. There is also a distinctive band near $800 \mathrm{~cm}^{-1}$. The overall topological
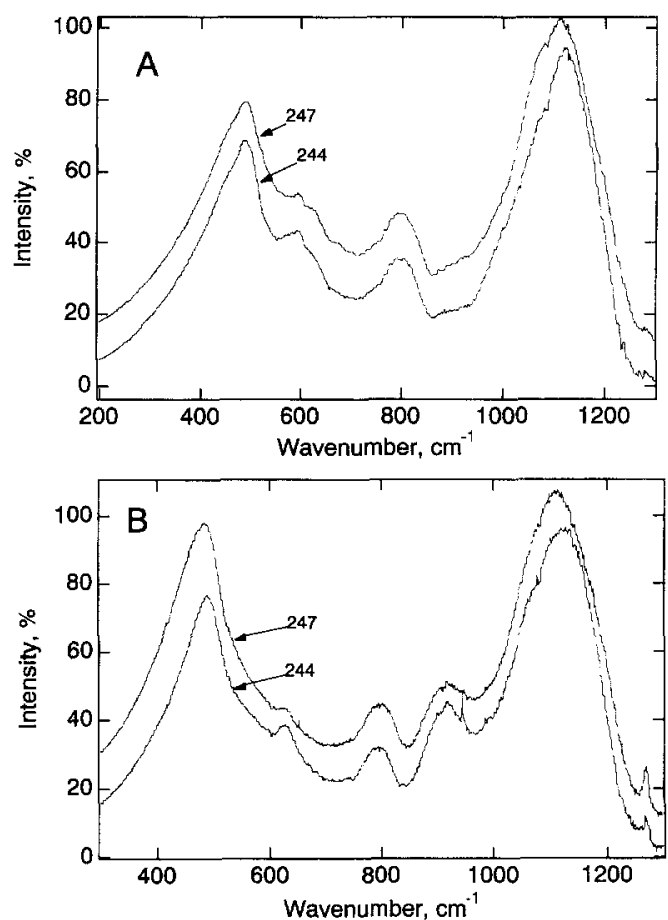

Fig. 2. Examples of unpolarized Raman spectra in the low-frequency region of nominally P-free (244) and P-bearing (247) glasses anhydrous (A) and hydrous (B).

features resemble those of other highly polymerized aluminosilicate glasses (e.g., McMillan et al., 1982; Seifert et al., 1982; Matson et al., 1986).
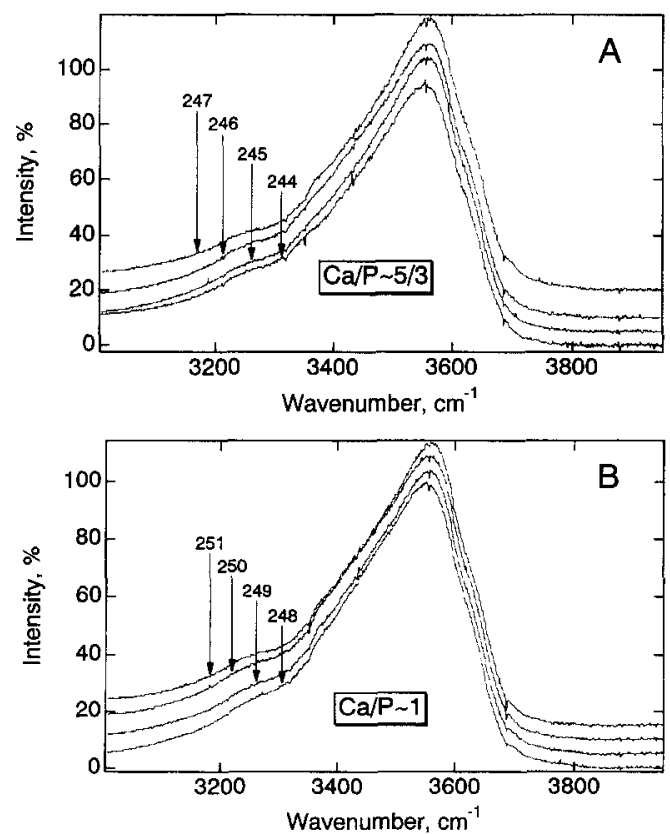

Fig. 3. Unpolarized Raman spectra in the spectral region of $\mathrm{OH}$ stretching. 


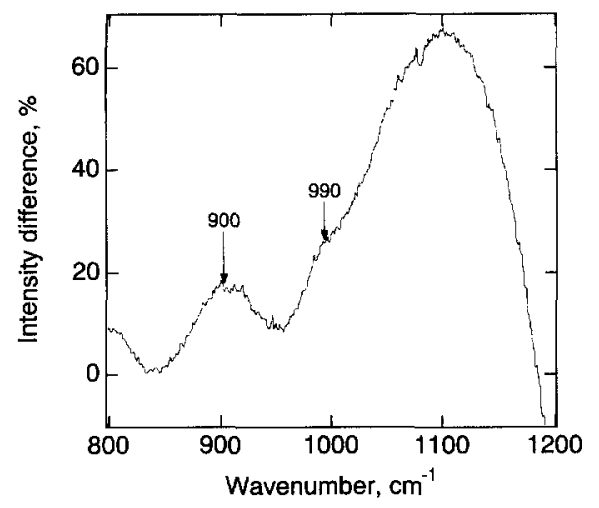

Fig. 4. Difference spectra (hydrous-anhydrous) in the $800-1200$ $\mathrm{cm}^{-1}$ range illustrating the influence of $\mathrm{H}_{2} \mathrm{O}$ on the Raman intensities. Sample 244 is nominally P-free.

In the $200-1300 \mathrm{~cm}^{-1}$ region, the principal spectral effect resulting from added $\mathrm{H}_{2} \mathrm{O}$ to the samples is the appearance of a broad strong band near $900 \mathrm{~cm}^{-1}$ (Fig. 2), an observation consistent with those of Mysen and Virgo (1986a) and McMillan et al. (1993). In both the P-free and P-bearing samples, the difference spectra (hydrous-anhydrous samples) also reveal a shoulder near $990 \mathrm{~cm}^{-1}$ (Fig. 4)

Addition of phosphorus to both hydrous and anhydrous samples, whether at $\mathrm{Ca} / \mathrm{P} \sim 5 / 3$ or $\mathrm{Ca} / \mathrm{P} \sim 1$, results only in subtle spectral changes (Fig. 2a, cf. spectrum 244, which is nominally P-free, and spectrum 247 , which contains nearly $3 \mathrm{wt} \% \mathrm{P}_{2} \mathrm{O}_{5}$ ). There appears to be a shoulder slightly below $1100 \mathrm{~cm}^{-1}$, a feature more clearly shown as a maximum near $1070 \mathrm{~cm}^{-1}$ in the difference spectra (P-bearing-P-free; see Fig. 5). In anhydrous samples with the highest $\mathrm{Ca} / \mathrm{P}$ $(\sim 5 / 3$; samples $245-247)$, a subtle intensity increase near $940 \mathrm{~cm}^{-1}$ with increasing phosphorus content may also be discerned (Fig. 5d). This latter effect is less clear in the samples with $\mathrm{Ca} / \mathrm{P} \sim 1$ ( samples 249-251; Fig. 5c). In the spectra of the hydrous glasses (Fig. 5a,b), this latter effect is obscured by the significant intensity increase near 970$990 \mathrm{~cm}^{-1}$ (see also Fig. 4). These spectral changes near 940 and $1100 \mathrm{~cm}^{-1}$ are qualitatively analogous to those of other P-bearing aluminosilicate glasses (e.g., Gan and Hess, 1992). The presence of phosphorus in the glasses also results in an intensity increase in the Raman spectra of such samples near $1210-1220 \mathrm{~cm}^{-1}$ (marked as 1210 in Fig. 5).

The spectra of P-bearing, hydrous samples (see Fig. 2b, for example) show the same overall topological features as the spectra of P-free hydrous samples. It is evident, however, that the intensity near $900 \mathrm{~cm}^{-1}$ diminishes with increasing P-content (and concomitant increase in peraluminosity; see Fig. 5a,b). Increasing P-content also results in enhanced intensity near $1070 \mathrm{~cm}^{-1}$ for the $\mathrm{Ca} / \mathrm{P} \sim 1$ series. This intensity change is less pronounced for hydrous samples with $\mathrm{Ca} / \mathrm{P} \sim 5 / 3$ (Fig. 5a,b).

\footnotetext{
This effect appears as an increasingly deep valley in the difference spectra in Fig. 5A,B.
}

\subsubsection{Curve-fitted spectra}

The spectral region between $\sim 850$ and $1250 \mathrm{~cm}^{-1}$ was fitted to Gaussian bands with the number of bands statistically determined as described above (experimental methods). Typical examples are shown in Fig. 6. A summary of the frequencies and areas of these bands is given in Table 2 .

The spectra of P-free, anhydrous glasses were fitted to a very weak band near $900 \mathrm{~cm}^{-1}$, and three strong bands near 1000,1100 , and $1200 \mathrm{~cm}^{-1}$, respectively, similar to other Raman data from highly polymerized aluminosilicate glasses (e.g., Seifert et al., 1982). For the anhydrous, P-bearing samples, the frequencies of the latter three bands are only very subtly dependent on the phosphorus content (Table 2). In the spectra of hydrous, both P-free and P-bearing samples. the frequencies of these latter three bands are distinctly higher (by as much as $20-30 \mathrm{~cm}^{-1}$ ) than in the spectra of the equivalent anhydrous samples. This observation accords with other spectroscopic data on the effect of $\mathrm{H}_{2} \mathrm{O}$ content on Raman frequencies in this frequency range for aluminosilicate glasses (Mysen and Virgo, 1986a).

In the presence of $\mathrm{H}_{2} \mathrm{O}$ (e.g., Fig. 6b,d; see also Tables 2 and 3 for complete set of data), a strong band occurs near $900 \mathrm{~cm}^{-1}$ in accord with other Raman and infrared spectroscopic data of hydrous aluminosilicate glasses (e.g., Mysen et al., 1980; Remmele et al., 1986; Mysen and Virgo, 1986a,b; Silver and Stolper, 1989; McMillan et al., 1993; Holtz et al., 1996). A band near $970 \mathrm{~cm}^{-1}$ is also observed (Fig. 6, see also Table 2). In the spectra of P-containing glasses, whether hydrous or anhydrous, two additional bands near 1100 and $1210 \mathrm{~cm}^{-1}$, respectively, are needed to satisfy the spectral envelope (e.g., Fig. 6). In the hydrous, phosphorus-bearing samples, a band near $940 \mathrm{~cm}^{-1}$ could also be fitted. This band is less evident in spectra of anhydrous, Pbearing samples ( Table 3 ). In all cases, whenever present the frequencies of the 940,1100 , and $1210 \mathrm{~cm}^{-1}$ bands appear insensitive to $\mathrm{H}_{2} \mathrm{O}$ and $\mathrm{P}$ concentrations (Table 2).

\subsection{High-Frequency Region $\left(3000-4000 \mathrm{~cm}^{-1}\right)$}

The high-frequency region between 3000 and $4000 \mathrm{~cm}^{1}$ of the spectra of all the hydrous samples is quite similar (Fig. 3) with a broad intensity maximum near $3600 \mathrm{~cm}^{-1}$, asymmetric toward lower frequencies and with a small shoulder near $\sim 3300 \mathrm{~cm}^{-1}$. This spectral topology is similar to that of other hydrous, highly polymerized aluminosilicate glasses (e.g., Mysen et al., 1980; Mysen and Virgo, 1986a,b; McMillan et al., 1993).

\subsubsection{Curve-fitted spectra}

In the curve-fitted spectra, four Gaussian bands near 3300 , 3500,3600 , and $3650 \mathrm{~cm}^{-1}$ were inserted (Fig. 7). Their

The anhydrous, P-free glasses (no. 244 and 248; see Table I) have NBO/T values of 0.022 and 0.027 , respectively. Thus any contribution from nonbridging oxygen is not likely to be detected in the Raman spectra. 

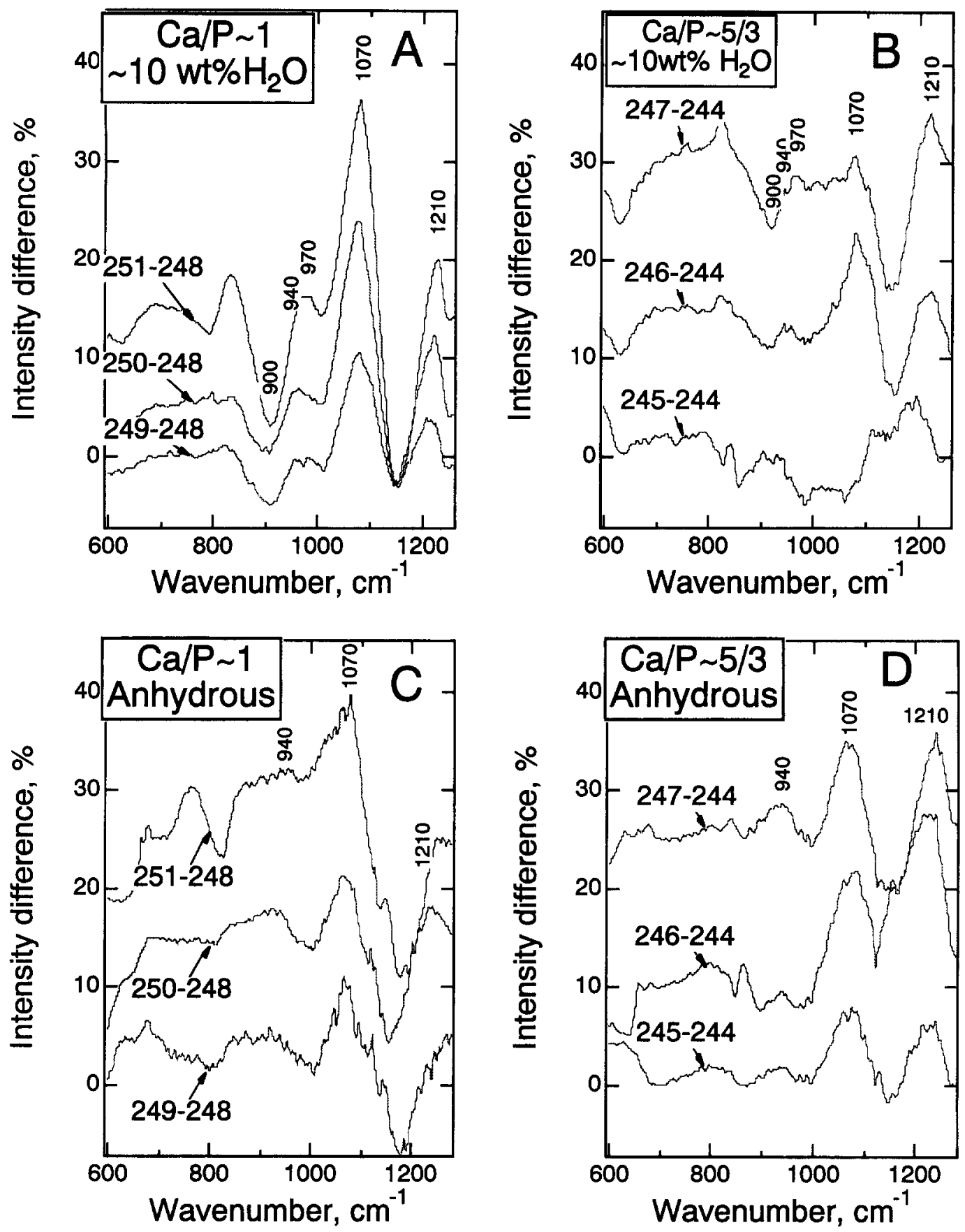

Fig. 5. Difference spectra illustrating the effect of increased phosphorus content for the two series of samples both anhydrous and hydrous. (A) The series $\mathrm{Ca} / \mathrm{P} \sim 1$ with approximately $10 \mathrm{wt} \% \mathrm{H}_{2} \mathrm{O}$ in solution. The spectra 249 , 250 , and 251 were subtracted from spectrum 248 (nominally P-free). (B) As A, but for the series $\mathrm{Ca} / \mathrm{P} \sim 5 / 3$. In this series spectra 245,246 , and 247 , were subtracted from the nominally P-free spectrum 244. (C) As A. but for anhydrous samples. (D) As B, but for anhydrous samples.

frequencies, with the exception of the band near $3300 \mathrm{~cm}^{-1}$, are insensitive to $\mathrm{Ca} / \mathrm{P}, \mathrm{A} / \mathrm{CNK}$, and phosphorus content (Table 4). The lowest-frequency band, near $3300 \mathrm{~cm}^{-1}$, exhibits a slight frequency decrease as the phosphorus content is increased (Table 4 ). The relative band areas vary systematically with $\mathrm{P}_{2} \mathrm{O}_{5}$ content (Fig. 8). Notably, in the
$\mathrm{Ca} / \mathrm{P} \sim 5 / 3$ series, the band near $3500 \mathrm{~cm}^{-1}$ grows and those near 3300 and $3600 \mathrm{~cm}^{-1}$ diminish, whereas the opposite trends with P-content is observed in the spectra of the $\mathrm{Ca} / \mathrm{P} \sim 1$ series of glasses (Fig. 8). The band near 3650 $\mathrm{cm}^{-1}$ is quite weak in all spectra ranging in relative area from 1.3 to $2.2 \%$ of the total area of the envelope. 

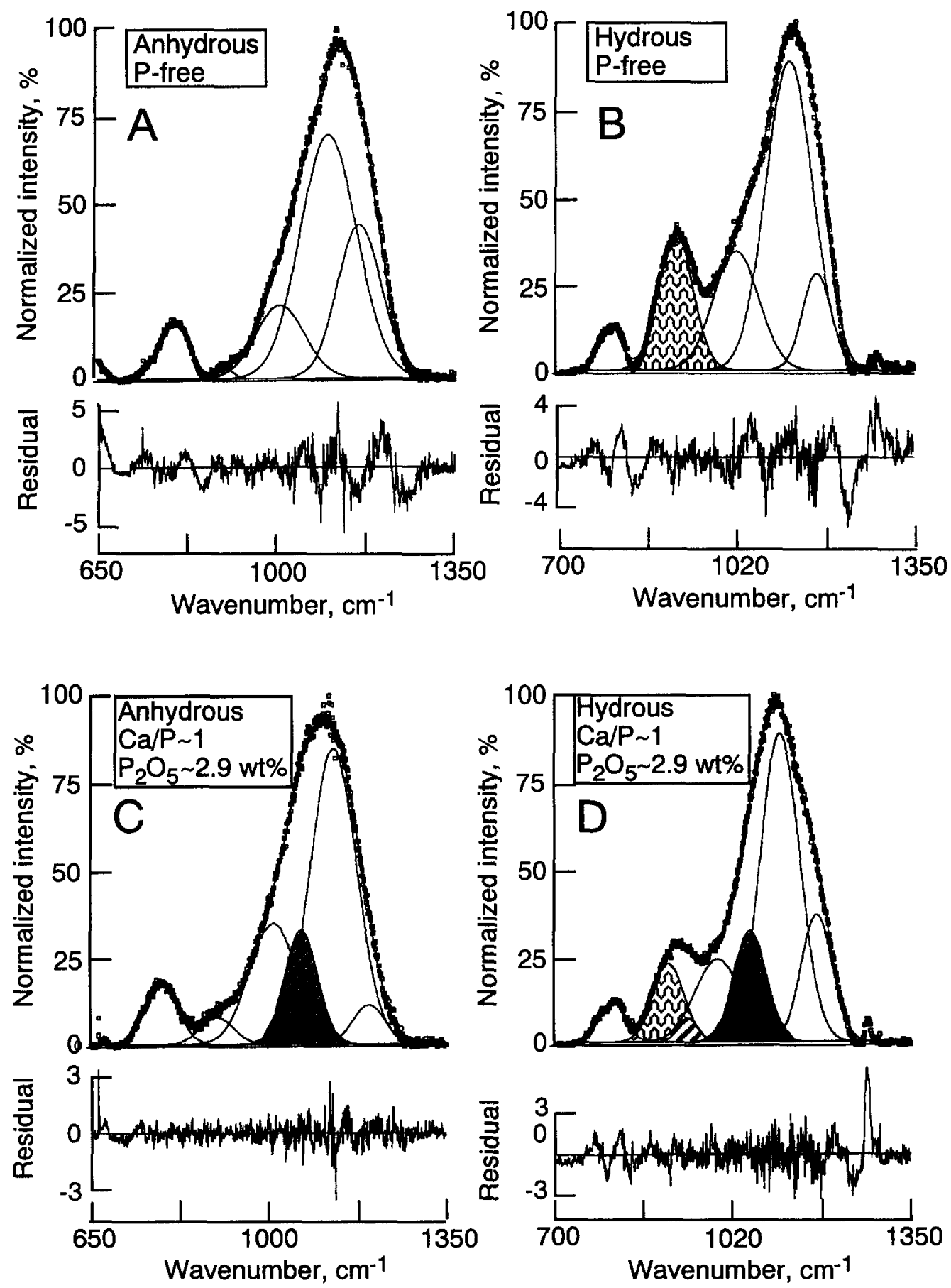

Fig. 6. Examples of curve-fitted spectra. Bands assigned to vibrations resulting from the presence of $\mathrm{H}_{2} \mathrm{O}$ are shown with dotted patterns, whereas bands assigned to vibrations associated with phosphorus are indicated with hachured patterns.

\subsection{Band Assignments and Structural Interpretation}

The starting point for interpretation of the aluminosilicate glass spectra is that of vitreous $\mathrm{SiO}_{2}$ where two average structures differing in the number of tetrahedra in the threedimensionally interconnected rings are commonly suggested
(Mammone et al., 1981; Galeener, 1982; Seifert et al., 1982, 1983; Revesz and Walrafen, 1983). These two ring structures give rise, for example, to the two bands near 1150 and $1200 \mathrm{~cm}^{-1}$ both of which are assigned to $\mathrm{Si}-\mathrm{O}^{\circ}$ stretch vibrations. A detailed analysis of spectra of glasses along the join $\mathrm{SiO}_{2}-\mathrm{NaAlO}_{2}$ led Seifert et al. (1982) to conclude 
Table 2. Experimental results - line parameters in $700-1300 \mathrm{~cm}^{-1}$ region.

\begin{tabular}{|c|c|c|c|c|c|c|c|c|c|}
\hline \multirow[b]{2}{*}{$\mathrm{wt} \% \mathrm{P}_{2} \mathrm{O}_{5}$} & \multirow[b]{2}{*}{$\mathrm{Al} /(\mathrm{Al}+\mathrm{Ca}+\mathrm{Na})$} & \multicolumn{8}{|c|}{ Frequency } \\
\hline & & 900 & 940 & 970 & 1000 & 1110 & 1100 & 1200 & 1210 \\
\hline \multicolumn{10}{|l|}{$\mathrm{Ca} / \mathrm{P} \sim 5 / 3$} \\
\hline \multicolumn{10}{|l|}{ Anhydrous } \\
\hline $\begin{array}{l}0.13 \\
1.11 \\
2.11 \\
2.55\end{array}$ & $\begin{array}{l}1.05 \\
1.15 \\
1.24 \\
1.34\end{array}$ & $\begin{array}{l}901 \\
912\end{array}$ & $\begin{array}{l}938 \\
938\end{array}$ & & $\begin{array}{r}1000 \\
996 \\
994 \\
990\end{array}$ & $\begin{array}{l}1119 \\
1117 \\
1118\end{array}$ & $\begin{array}{l}1092 \\
1080 \\
1077 \\
1073\end{array}$ & $\begin{array}{l}1160 \\
1158 \\
1154 \\
1151\end{array}$ & $\begin{array}{l}1205 \\
1205 \\
1211\end{array}$ \\
\hline \multicolumn{10}{|c|}{$\sim 10 \mathrm{wt} \% \mathrm{H}_{2} \mathrm{O}$} \\
\hline $\begin{array}{l}0.13 \\
1.11 \\
2.11 \\
2.55\end{array}$ & $\begin{array}{l}1.05 \\
1.15 \\
1.24 \\
1.34\end{array}$ & $\begin{array}{l}912 \\
907 \\
907 \\
906\end{array}$ & $\begin{array}{l}939 \\
940 \\
939\end{array}$ & $\begin{array}{l}976 \\
970 \\
977 \\
976\end{array}$ & $\begin{array}{l}1045 \\
1043 \\
1037 \\
1036\end{array}$ & $\begin{array}{l}1121 \\
1123 \\
1123\end{array}$ & $\begin{array}{l}1124 \\
1112 \\
1102 \\
1102\end{array}$ & $\begin{array}{l}1180 \\
1173 \\
1173 \\
1175\end{array}$ & $\begin{array}{l}1211 \\
1212 \\
1211\end{array}$ \\
\hline \multicolumn{10}{|l|}{$\mathrm{Ca} / \mathrm{P} \sim \mathrm{I}$} \\
\hline \multicolumn{10}{|l|}{ Anbydrous } \\
\hline $\begin{array}{l}0.15 \\
1.08 \\
2.24 \\
2.86\end{array}$ & $\begin{array}{l}1.04 \\
1.16 \\
1.22 \\
1.32\end{array}$ & $\begin{array}{l}900 \\
910 \\
915 \\
906\end{array}$ & & & $\begin{array}{r}1002 \\
997 \\
995 \\
997\end{array}$ & $\begin{array}{l}1118 \\
1120 \\
1116\end{array}$ & $\begin{array}{l}1092 \\
1080 \\
1079 \\
1078\end{array}$ & $\begin{array}{l}1160 \\
1154 \\
1154 \\
1154\end{array}$ & $\begin{array}{l}1205 \\
1206 \\
1205\end{array}$ \\
\hline \multicolumn{10}{|c|}{$\sim 10 \mathrm{wt} \% \mathrm{H}_{2} \mathrm{O}$} \\
\hline $\begin{array}{l}0.15 \\
1.08 \\
2.24 \\
2.86\end{array}$ & $\begin{array}{l}1.04 \\
1.16 \\
1.22 \\
1.32\end{array}$ & $\begin{array}{l}912 \\
904 \\
904 \\
906\end{array}$ & $\begin{array}{l}938 \\
937 \\
937\end{array}$ & $\begin{array}{l}968 \\
974 \\
971 \\
977\end{array}$ & $\begin{array}{l}1046 \\
1042 \\
1040 \\
1038\end{array}$ & $\begin{array}{l}1122 \\
1124 \\
1122 \\
\end{array}$ & $\begin{array}{l}1126 \\
1109 \\
1102 \\
1101\end{array}$ & $\begin{array}{l}1178 \\
1173 \\
1172 \\
1172 \\
\end{array}$ & $\begin{array}{l}1211 \\
1210 \\
1210\end{array}$ \\
\hline
\end{tabular}

Areas

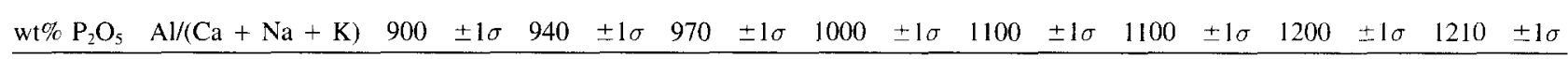

$\mathrm{Ca} / \mathrm{P} \sim 5 / 3$

Anhydrous

\begin{tabular}{|c|c|c|c|c|c|c|c|c|c|c|c|c|c|c|c|c|c|}
\hline 0.13 & 1.05 & 50 & 21 & & & & & 1027 & 104 & & & 4683 & 285 & 3266 & 248 & & \\
\hline 1.11 & 1.15 & 92 & 28 & & & & & 1066 & 69 & 880 & 50 & 4232 & 129 & 2121 & 102 & 1169 & 71 \\
\hline 2.11 & 1.24 & & & 27 & 19 & & & 654 & 65 & 785 & 78 & 4566 & 120 & 2371 & 208 & 1859 & 146 \\
\hline 2.55 & 1.34 & & & 303 & 49 & & & 506 & 57 & 235 & 30 & 4339 & 116 & 3197 & 76 & 874 & 42 \\
\hline \multicolumn{18}{|c|}{$\sim 10 \mathrm{wt} \% \mathrm{H}_{2} \mathrm{O}$} \\
\hline 0.13 & 1.05 & 941 & 48 & & & 870 & 60 & 1299 & 60 & & & 6546 & 118 & 471 & 41 & & \\
\hline 1.11 & 1.15 & 745 & 35 & 223 & 38 & 499 & 84 & 1527 & 145 & 496 & 64 & 4349 & 175 & 1912 & 89 & 52 & 17 \\
\hline 2.11 & 1.24 & 740 & 60 & 283 & 99 & 467 & 201 & 1121 & 329 & 418 & 240 & 5042 & 485 & 1683 & 225 & 224 & 83 \\
\hline 2.55 & 1.34 & 583 & 50 & 253 & 85 & 609 & 98 & 1039 & 78 & 421 & 209 & 4986 & 299 & 2001 & 62 & 153 & 32 \\
\hline
\end{tabular}

$\mathrm{Ca} / \mathrm{P} \sim \mathrm{I}$

Anhydrous

\begin{tabular}{|c|c|c|c|c|c|c|c|c|c|c|c|c|c|c|c|c|c|}
\hline 0.15 & 1.04 & 80 & 29 & & & & & 1182 & 98 & & & 4691 & 158 & 3756 & 127 & & \\
\hline 1.08 & 1.16 & 139 & 33 & & & & & 1110 & 116 & 515 & 41 & 4170 & 196 & 2439 & 115 & 1038 & 70 \\
\hline 2.24 & 1.22 & 288 & 46 & & & & & 911 & 55 & 377 & 30 & 4366 & 102 & 2457 & 78 & 1026 & 61 \\
\hline 2.86 & 1.32 & 115 & 31 & & & & & 1343 & 111 & 793 & 103 & 4291 & 198 & 2341 & 94 & 641 & 70 \\
\hline \multicolumn{18}{|c|}{$\sim 10 \mathrm{wt} \% \quad \mathrm{H}_{2} \mathrm{O}$} \\
\hline 0.15 & 1.04 & 1281 & 70 & & & 819 & 66 & 1820 & 49 & & & 4753 & 99 & 1107 & 52 & & \\
\hline 1.08 & 1.16 & 757 & 38 & 384 & 54 & 547 & 80 & 1348 & 80 & 829 & 66 & 4091 & 109 & 1713 & 61 & 27 & 10 \\
\hline 2.24 & 1.22 & 812 & 47 & 443 & 36 & 457 & 50 & 1473 & 313 & 629 & 255 & 4503 & 632 & 1681 & 398 & 170 & 106 \\
\hline 2.86 & 1.32 & 570 & 37 & 367 & 61 & 572 & 121 & 1000 & 224 & 410 & 171 & 4852 & 403 & 1383 & 124 & 172 & 103 \\
\hline
\end{tabular}


Table 3. Area of $940 \mathrm{~cm}^{-1}$ band relative to total area ${ }^{\#}$ of highfrequency envelope $\left(850-1300 \mathrm{~cm}^{-1}\right)$.

\begin{tabular}{cccc}
\hline $\mathrm{Wt} \% \mathrm{P}_{2} \mathrm{O}_{2}$ & $\mathrm{~A} / \mathrm{CNK} *$ & Hydrous $( \pm 1 \sigma)$ & Anhydrous $( \pm 1 \sigma)$ \\
\hline $\mathrm{Ca} / \mathrm{P} \sim 5 / 3$ & & & \\
1.11 & 1.15 & $0.024(4)$ & n.d. \\
2.11 & 1.24 & $0.030(10)$ & $0.003(2)$ \\
2.55 & 1.34 & $0.027(9)$ & $0.004(5)$ \\
& & & \\
$\mathrm{Ca} / \mathrm{P} \sim 1$ & & & \\
1.08 & 1.15 & $0.042(6)$ & n.d. \\
2.24 & 1.24 & $0.046(4)$ & n.d. \\
2.86 & 1.34 & $0.042(7)$ & n.d. \\
\hline
\end{tabular}

\# The area of the $970 \mathrm{~cm}^{-1}$ band not included. n.d. Not Detected.

* Molar $\mathrm{Al}_{2} \mathrm{O}_{3} /\left(\mathrm{CaO}+\mathrm{Na}_{2} \mathrm{O}+\mathrm{K}_{2} \mathrm{O}\right)$.

that a similar structural environment existed as $\mathrm{Al}^{3+}$ substituted for $\mathrm{Si}^{4+}$ in glasses along this join. The frequencies of the bands near 1150 and $1200 \mathrm{~cm}^{-1}$ in spectra of vitreous $\mathrm{SiO}_{2}$ decreased systematically with increasing $\mathrm{Al} /(\mathrm{Al}+\mathrm{Si})$. In the present spectra of anhydrous, P-free glasses, bands assigned to $(\mathrm{Si}, \mathrm{Al})-\mathrm{O}^{\circ}$ stretching, occur near 1090 and 1160 $\mathrm{cm}^{-1}$, respectively (Table 2 ; see also Fig. 6a).

The assignment of the $\sim 900 \mathrm{~cm}^{-1}$ band in spectra of all hydrous samples (whether P-bearing or nominally P-free) as well as in published spectra of other hydrous aluminosilicate glasses has been the subject of debate. One assignment is to ( $\mathrm{Si}, \mathrm{Al}$ )-OH stretch vibrations (e.g., Remmele et al., 1986; McMillan et al., 1993). From multinuclear NMR $\left({ }^{23} \mathrm{Na},{ }^{27} \mathrm{Al},{ }^{29} \mathrm{Si}\right)$, Kohn et al. $(1989,1992)$ concluded, how- ever, that in melt of albite composition there is no evidence for $\mathrm{Al}-\mathrm{OH}$ or $\mathrm{Si}-\mathrm{OH}$ bonding but, rather that the principal $\mathrm{OH}$-formation is through interaction with alkalis. Thus, the inference from the NMR data is inconsistent with the assignment of the $900 \mathrm{~cm}^{-1}$ band to ( $\left.\mathrm{Si}, \mathrm{Al}\right)-\mathrm{OH}$ stretching. The observation (Mysen and Virgo, 1986a) that the intensity of this band increases continuously with increasing $\mathrm{H}_{2} \mathrm{O}$ content (up to $8-10$ wt $\% \mathrm{H}_{2} \mathrm{O}$ ) also is inconsistent with an assignment to ( $\mathrm{Si}, \mathrm{Al}$ )-OH. This inconsistency is because in hydrous aluminosilicate glasses with total $\mathrm{H}_{2} \mathrm{O}$ content above $\sim 3$ wt \% results from IR spectroscopy (e.g., Stolper, 1982; Silver and Stolper, 1989; Silver et al., 1990) show that any additional $\mathrm{H}_{2} \mathrm{O}$ is dissolved in molecular form. Thus, one would not expect the $900 \mathrm{~cm}^{-1}$ band intensity to increase if it was assigned to any kind of vibration associated with structurally bound $\mathrm{OH}$ groups. Others have assigned the 900 $\mathrm{cm}^{-1}$ band to $(\mathrm{Si}, \mathrm{Al})-\mathrm{O}^{-}$stretching arising from the presence of nonbridging oxygen in the hydrous samples (e.g., Mysen and Virgo, 1986a). Such proposed nonbridging oxygen could be as the result of formation either of $\mathrm{M}-\mathrm{OH}$ or $\mathrm{Al}-$ $\mathrm{OH}$ complexes. By forming $\mathrm{M}-\mathrm{OH}$ complexes, the chargebalance requirement of $\mathrm{Al}^{3+}$ in tetrahedral coordination is no longer met. By forming Al-OH complexes, there would be an excess M-cations. In either case, nonbridging oxygen would be formed. (This effect is illustrated with Eqns. 9 and 10 and Table $\mathrm{V}$ in Mysen and Virgo, 1986a.) Although clearly more information is needed before the issue can be fully resolved, in the absence of evidence to the contrary, we assign the $900 \mathrm{~cm}^{-1}$ band to $(\mathrm{Si}, \mathrm{Al})-\mathrm{O}^{-}$stretching in a depolymerized structural unit (probably of $Q^{2}$ type). The spectral interpretation is also consistent with results from anhydrous peralkaline melts and glasses in, for the example, the system $\mathrm{Na}_{2} \mathrm{O}-\mathrm{Al}_{2} \mathrm{O}_{3}-\mathrm{SiO}_{2}$. Spectra of melt and glasses in
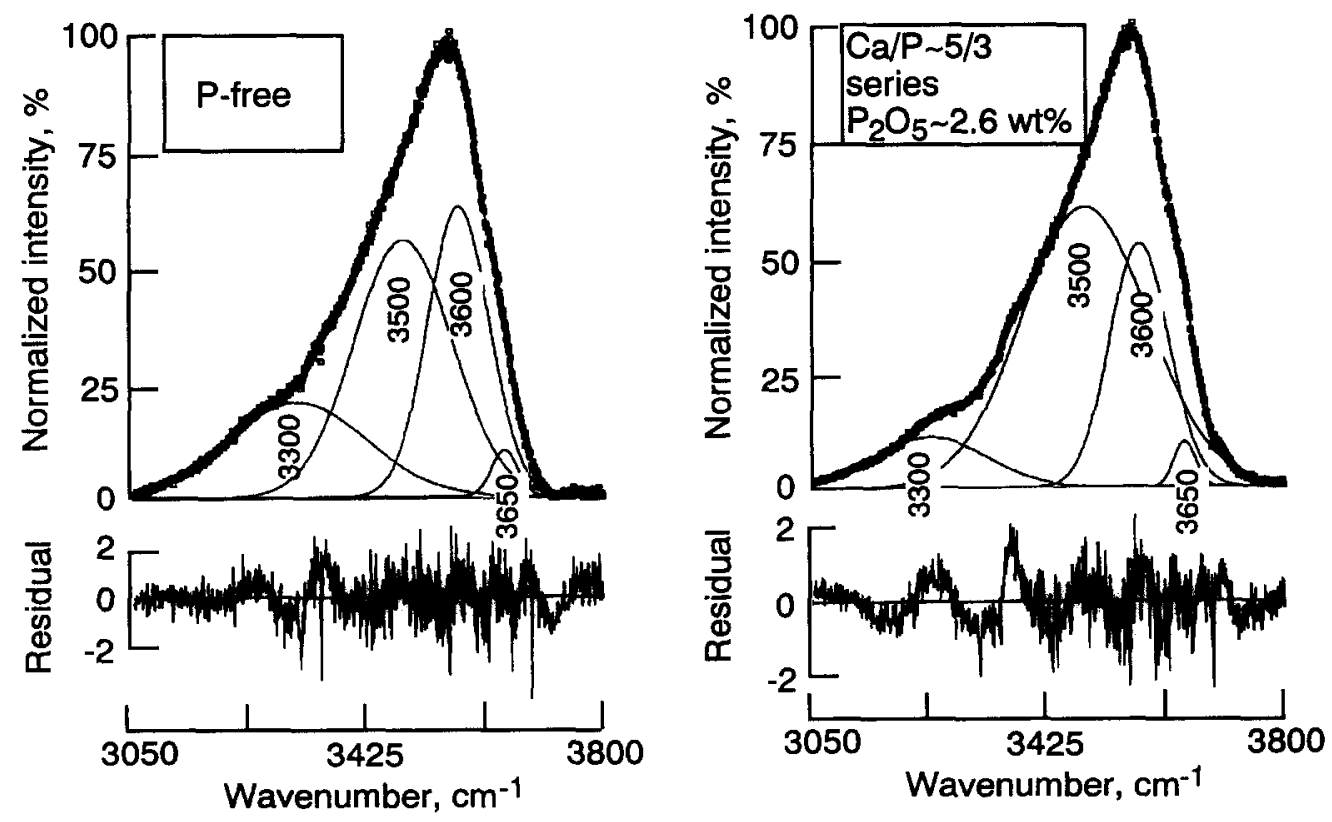

Fig. 7. Examples of curve-fitted spectra in the region of $\mathrm{OH}$ stretching. 
Table 4. Experimental results -- line parameters in the $3000-4000 \mathrm{~cm}^{-1}$ region.

\begin{tabular}{|c|c|c|c|c|c|c|c|c|c|}
\hline \multirow[b]{2}{*}{$\mathrm{Wt} \% \mathrm{P}_{2} \mathrm{O}_{5}$} & \multirow[b]{2}{*}{ A/CNK* } & \multicolumn{4}{|c|}{ Frequency } & \multicolumn{4}{|c|}{ Area } \\
\hline & & 3300 & 3500 & 3600 & 3650 & 3300 & 3500 & 3600 & 3650 \\
\hline \multicolumn{10}{|l|}{$\mathrm{Ca} / \mathrm{P} \sim 5 / 3$} \\
\hline $\begin{array}{l}0.13 \\
1.11 \\
2.11 \\
2.55\end{array}$ & $\begin{array}{l}1.05 \\
1.15 \\
1.24 \\
1.34\end{array}$ & $\begin{array}{l}3316 \\
3291 \\
3279 \\
3245\end{array}$ & $\begin{array}{l}3484 \\
3495 \\
3487 \\
3488\end{array}$ & $\begin{array}{l}3572 \\
3573 \\
3574 \\
3573\end{array}$ & $\begin{array}{l}3644 \\
3645 \\
3644 \\
3644\end{array}$ & $\begin{array}{l}3152 \\
2870 \\
2519 \\
1406\end{array}$ & $\begin{array}{l}6086 \\
7791 \\
8152 \\
8605\end{array}$ & $\begin{array}{l}4305 \\
3432 \\
3585 \\
3512\end{array}$ & $\begin{array}{l}294 \\
257 \\
246 \\
242\end{array}$ \\
\hline \multicolumn{10}{|l|}{$\mathrm{Ca} / \mathrm{P} \sim 1$} \\
\hline $\begin{array}{l}0.15 \\
1.08 \\
2.24 \\
2.86\end{array}$ & $\begin{array}{l}1.05 \\
1.15 \\
1.24 \\
1.34\end{array}$ & $\begin{array}{l}3268 \\
3268 \\
3256 \\
3258\end{array}$ & $\begin{array}{l}3481 \\
3485 \\
3471 \\
3477\end{array}$ & $\begin{array}{l}3571 \\
3572 \\
3572 \\
3573\end{array}$ & $\begin{array}{l}3639 \\
3643 \\
3644 \\
3645\end{array}$ & $\begin{array}{l}2106 \\
2119 \\
1953 \\
1743\end{array}$ & $\begin{array}{l}8707 \\
8570 \\
7936 \\
7707\end{array}$ & $\begin{array}{l}3497 \\
3399 \\
4348 \\
4089\end{array}$ & $\begin{array}{l}210 \\
215 \\
231 \\
256\end{array}$ \\
\hline
\end{tabular}

* Molar $\mathrm{Al}_{2} \mathrm{O}_{3} /\left(\mathrm{CaO}+\mathrm{Na}_{2} \mathrm{O}+\mathrm{K}_{2} \mathrm{O}\right)$.

this system reveal significant reduction in frequencies of bands assigned to $\mathrm{Si}_{-} \mathrm{O}^{-}$stretching as the $\mathrm{Al} /(\mathrm{Al}+\mathrm{Si})$ of the system is increased (Mysen and Frantz, 1994).

The relative intensity of the $900 \mathrm{~cm}^{-1}$ band could then be a measure of degree of polymerization of the melts. Interestingly, the area of this band is greater in all the spectra of samples from the $\mathrm{Ca} / \mathrm{P} \sim 1$ series. Furthermore, in both series, its relative area decreases somewhat with increasing phosphorus content ( Fig. 9). Consequently, one may suggest that in hydrous aluminosilicate melts, $\mathrm{P}$ acts as a polymerizing agent analogous to the structural role of phosphorus in
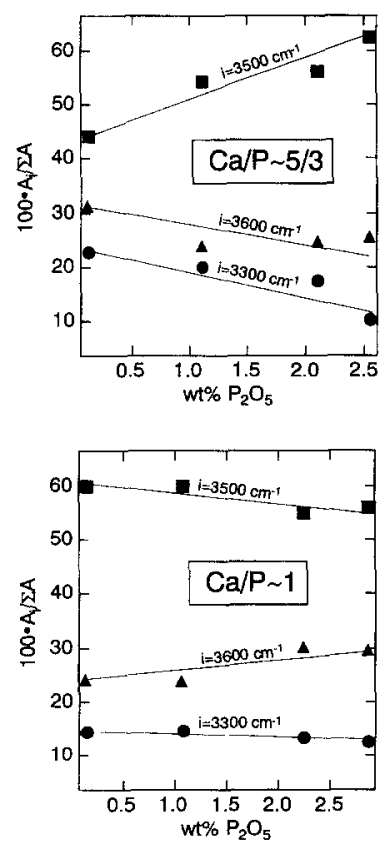

Fig. 8. Variations in areas of individual bands in the $\mathrm{OH}$ stretch region relative to the total area of the envelope, $\Sigma \mathrm{A}$, as a function of $\mathrm{wt} \% \mathrm{P}_{2} \mathrm{O}_{5}$ (and $\mathrm{A} / \mathrm{CNK}$, see Fig. 1). anhydrous depolymerized melts (Dupree et al., 1988, 1989; Mysen, 1992). The actual value of NBO/T contributing to the $900 \mathrm{~cm}^{-1}$ band intensity may be estimated with the method proposed by Mysen and Virgo (1986a). From such calculations, it would appear that solution of $\sim 9-10 \mathrm{wt} \%$ $\mathrm{H}_{2} \mathrm{O}$ has increased the NBO/T from near 0 for anhydrous samples to about 0.7 in the hydrous glasses, a value similar to that of trisilicate glasses, for example. There is a $10-25 \%$ decrease in this NBO/T-value as phosphorus is dissolved (Table 5).

The Raman band fitted near $970-975 \mathrm{~cm}^{-1}$ in the spectra of hydrous glasses, with composition-independent frequency, is assigned to Si-OH stretching (e.g., Stolen and Walrafen, 1976). The presence of Si-OH bonding in these glasses is also consistent with the band near $3650 \mathrm{~cm}^{-1}$ in the high-frequency envelope (e.g., Fig. 7, see also Table 4) as $\mathrm{OH}$ stretch vibrations at this high frequency has not been associated with hydroxyl formation involving the other metal cations ( $\mathrm{Al}, \mathrm{Ca}, \mathrm{Na}, \mathrm{K}$ ) in the present system (e.g., Aines and Rossman, 1984; Mysen and Virgo, 1986a,b). The dominant intensity in the $3000-4000 \mathrm{~cm}^{-1}$ range at lower frequency

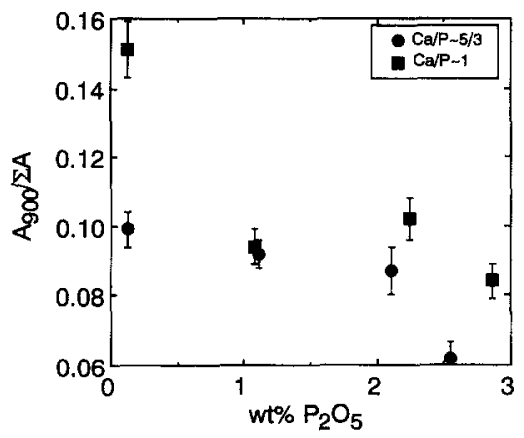

Fig. 9. Relationship between phosphorus content (and A/CNK) the area of the $900 \mathrm{~cm}^{-1}$ band $\left(A_{900}\right)$ relative to the total area of bands assigned to vibrations not including $\mathrm{OH}\left(970 \mathrm{~cm}^{-1}\right)$ and $\mathrm{P}$ ( 1120 and $\left.1210 \mathrm{~cm}^{-1}\right) \cdot \Sigma \mathrm{A}=\mathrm{A}_{900}+\mathrm{A}_{1000}+\mathrm{A}_{155} \mathrm{O}+\mathrm{A}_{120 \%)}$. 
Table 5. Calculated NBO/T from relative area of $900 \mathrm{~cm}^{-1}$ band.

\begin{tabular}{ccc}
\hline $\mathrm{Wt} \% \mathrm{P}_{2} \mathrm{O}_{5}$ & $\mathrm{~A} / \mathrm{CNK}^{*}$ & $\mathrm{NBO} / \mathrm{T}( \pm 1 \sigma)$ \\
\hline $\mathrm{Ca} / \mathrm{P} \sim 5 / 3$ & & \\
0.13 & 1.05 & $0.76(8)$ \\
1.11 & 1.15 & $0.59(6)$ \\
2.11 & 1.24 & $0.72(8)$ \\
2.55 & 1.34 & $0.65(7)$ \\
& & \\
$\mathrm{Ca} / \mathrm{P} \sim 1$ & & \\
0.15 & 1.05 & $0.74(8)$ \\
1.08 & 1.15 & $0.65(7)$ \\
2.24 & 1.24 & $0.64(7)$ \\
2.86 & 1.34 & $0.65(7)$ \\
\hline
\end{tabular}

* Molar $\mathrm{Al}_{2} \mathrm{O}_{3} /\left(\mathrm{CaO}+\mathrm{Na}_{2} \mathrm{O}+\mathrm{K}_{2} \mathrm{O}\right)$.

(e.g., Figs. 7, 8) is consistent with a significant fraction of the $\mathrm{OH}$-groups bonded to metal cations other than $\mathrm{Si}^{4+}$ (e.g., Mysen and Virgo, 1986b). This conclusion is also consistent with multinuclear NMR data of hydrous, highly polymerized aluminosilicate melts suggesting primarily alkali-OH interaction (e.g., Kohn et al., 1992).

The three remaining bands in the high-frequency envelope is that near $940-950 \mathrm{~cm}^{-1}$ and those near 1120 and 1210 $\mathrm{cm}^{-1}$ (Fig. 6). The latter two bands are observed only when there is $\mathbf{P}$ in the system. It is suggested that the band fitted near $1120 \mathrm{~cm}^{-1}$ might be assigned to $\mathrm{P}-\mathrm{O}-\mathrm{Al}$ stretching thus, in accord with Gan and Hess (1992), leading to the suggestion that phosphate complexing with $\mathrm{Al}$ occurs in peraluminous glasses to form perhaps $\mathrm{P}-\mathrm{O}-\mathrm{Al}$ linkages in a threedimensional structure (see also Mysen et al., 1981).

The band near $1210 \mathrm{~cm}^{-1}$ will be interpreted with the aid of published Raman and ${ }^{31} \mathrm{P}$ NMR data (Chakraborty and Condrate, 1985; Kosinski et al., 1988; Dupree et al., 1989). In a vibrational spectroscopic study that included Raman data for $\mathrm{Na}_{2} \mathrm{O}-\mathrm{SiO}_{2}-\mathrm{P}_{2} \mathrm{O}_{5}$ glasses, Chakraborty and Condrate (1985) suggested that a band near $1180 \mathrm{~cm}^{-1}$ in their spectra could be assigned to coupled vibrations of $\mathrm{Si}-\mathrm{O}$ and $\mathrm{P}-\mathrm{O}$ stretching coordinates. Chakraborty and Condrate (1985) on this basis concluded that this was evidence for Si-O-P linkages in their $\mathrm{Na}_{2} \mathrm{O}-\mathrm{SiO}_{2}-\mathrm{P}_{2} \mathrm{O}_{5}$ glasses. Kosinski et al. (1988) and Dupree et al. ( 1989) reported ${ }^{31} \mathrm{P}$ NMR evidence for Si$\mathrm{O}-\mathrm{P}$ linkages in P-bearing alkali silicate and alkali aluminosilicate glasses. Additionally, Kosinski et al. (1988) suggested that Raman bands in the $1100-1250 \mathrm{~cm}^{-1}$ frequency range included vibrations due to Si-O-P linkages. Mysen et al. (1981) in a study of P-bearing $\mathrm{NaAlSi}_{3} \mathrm{O}_{8}$ and $\mathrm{CaAl}_{2}$ $\mathrm{Si}_{2} \mathrm{O}_{8}$ glasses suggested that a band near $1150 \mathrm{~cm}^{-1}$ reflected the presence of Si-O-P linkages in those materials. Although somewhat uncertain, we suggest that the band fitted near $1210 \mathrm{~cm}^{-1}$ in the spectra of the present glasses also reflects the presence of Si-O-P linkages in the glasses studied here. This suggestion implies structural cross-linking between the phosphate and silicate portion of both the hydrous and anhydrous, peraluminous aluminosilicate glasses.
The area ratio, $\mathrm{A}_{1120} /\left(\mathrm{A}_{1120}+\mathrm{A}_{1210}\right)$, might be taken as a measure of the relative abundance of $\mathrm{P}-\mathrm{O}-\mathrm{Al}$ and $\mathrm{P}-\mathrm{O}-\mathrm{Si}$ linkages (although this abundance ratio cannot be quantified from the Raman spectra). From the much larger values of $A_{1120} /\left(A_{1120}+A_{1210}\right)$ in spectra of hydrous as compared with anhydrous samples (Fig. 10) it follows that P-O-Al linkages are more abundant in the hydrous than in the anhydrous $\mathrm{P}$ bearing aluminosilicate glasses.

The $940 \mathrm{~cm}^{1}$ band is significant only in the spectra of hydrous P-bearing samples (Table 3; see also Fig. 6). In these samples, its relative intensity is greater in the series of samples with lowest $\mathrm{Ca} / \mathrm{P}$ (Table 3 ). This band could be assigned to $\mathrm{P}_{-} \mathrm{O}^{-}$stretching in an orthophosphate $\left(\mathrm{PO}_{4}^{3-}\right)$ unit (e.g., Nelson and Tallant, 1986; Mysen, 1992). The frequency, however, is about $20 \mathrm{~cm}^{-1}$ lower than that observed in many crystalline orthophosphates and also in spectra of other P-bearing glasses where independent spectroscopic evidence indicates that orthophosphate complexes exist (e.g., Nelson and Tallant, 1986; Dupree et al., 1988). Further, Raman spectra of $\mathrm{CaO}-\mathrm{SiO}_{2}-\mathrm{P}_{2} \mathrm{O}_{5}$ and $\mathrm{Na}_{2} \mathrm{O}-\mathrm{SiO}_{2}-$ $\mathrm{P}_{2} \mathrm{O}_{5}$ glasses show the band assigned to $\mathrm{P}_{-} \mathrm{O}^{-}$stretching in orthosilicate units as a narrow band between 960 and 965 $\mathrm{cm}^{-1}$ (Mysen, 1992, 1996). In the present system, with similar metal cations, one would, therefore, expect the frequency to be near $960 \mathrm{~cm}^{-1}$ and not $940 \mathrm{~cm}^{-1}$ as observed. It should also be noted that despite this inconsistency, if the $940 \mathrm{~cm}^{-1}$ band was due to $\mathrm{P}_{-} \mathrm{O}^{-}$stretching in orthophosphate units in the hydrous samples, from a comparison of the intensity data from the system $\mathrm{Na}_{2} \mathrm{O} \cdot 9 \mathrm{SiO}_{2}(\mathrm{NBO} / \mathrm{Si}=0.22)$ with 2 mol\% $\mathrm{P}_{2} \mathrm{O}_{5}$ in solution with the present intensity relationships, it would be suggested that even in the most P-rich sample, only about $10 \%$ of the dissolved $\mathrm{P}_{2} \mathrm{O}_{5}$ would exist as orthophosphate.

An alternative interpretation may be related to the observation above (e.g., Fig. 10) that the abundance of P-O-Si relative to $\mathrm{P}-\mathrm{O}-\mathrm{Al}$ linkages decreases as $\mathrm{H}_{2} \mathrm{O}$ is dissolved in the glasses. This structural change might imply that P-O-Si oxygen bridges have been broken by $\mathrm{H}_{2} \mathrm{O}$. Such breakage could lead to formation of Si-OH and P-OH bonds (analogous to the breakage of $\mathrm{Si}-\mathrm{O}-\mathrm{Si}$ bridges to form two $\mathrm{Si}$ $\mathrm{OH}$ bonds in $\mathrm{SiO}_{2}-\mathrm{H}_{2} \mathrm{O}$ glasses and melts; see, for example, Wasserburg, 1957; Stolen and Walrafen, 1976). It is possible that the $940 \mathrm{~cm}$ ' might be assigned to an equivalent $\mathrm{P}-\mathrm{OH}$ vibration.

In the study of Mysen and Virgo (1986b), the area of the band near $3500 \mathrm{~cm}^{-1}$ was found particularly sensitive to $\mathrm{Ca} /$ Si ratio (in spectra of glasses along the join $\mathrm{Ca}(\mathrm{OH})_{2}-\mathrm{SiO}_{2}$ ), whereas the area of lower-frequency band, near $3300 \mathrm{~cm}^{-1}$, appeared positively correlated with $\mathrm{Na} / \mathrm{Si}$ (in spectra of glasses along the join $\mathrm{NaOH}-\mathrm{SiO}_{2}$ ). This latter frequency region also, however, exhibits increased intensity with increasing abundance of molecular $\mathrm{H}_{2} \mathrm{O}$ so interpretation of the intensity variations in this region of spectra from the more complex aluminosilicate glasses should be conducted with caution. A band near $3600 \mathrm{~cm}^{-1}$ occurred in spectra of glasses along both the joins $\mathrm{Al}(\mathrm{OH})_{3}-\mathrm{SiO}_{2}$ and $\mathrm{SiO}_{2}-\mathrm{H}_{2} \mathrm{O}$ (Mysen and Virgo, 1986b). Relative intensity variations re- 

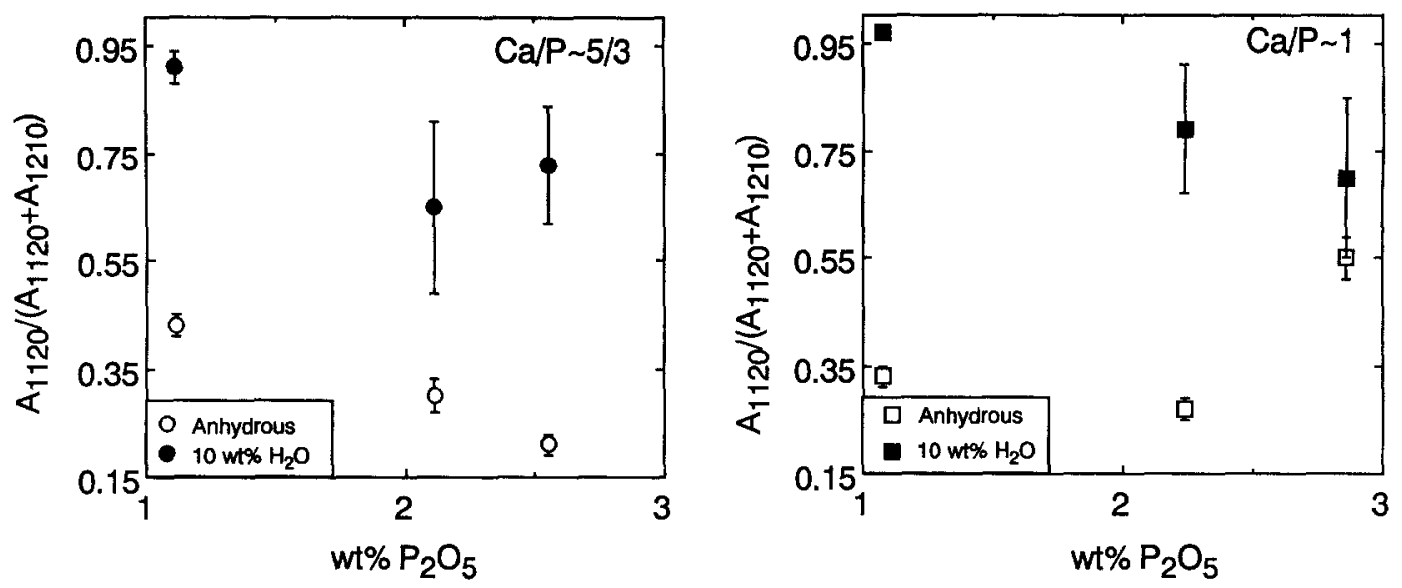

Fig. 10. Relative intensities of the two bands assigned to P-O-Al $\left(\mathrm{A}_{1120}\right)$ and P-O-Si $\left(\mathrm{A}_{1210}\right)$ as a function of phosphorus content (and A/CNK) for hydrous (closed symbols) and anhydrous (open symbols) samples.

flecting possible variations in abundance of $\mathrm{Al}-\mathrm{OH}$ and $\mathrm{Si}-$ $\mathrm{OH}$ bonding is, therefore, not feasible. It is tentatively suggested, however, that the intensity variations among the 3500 and $3300 \mathrm{~cm}^{-1}$ bands (Fig. 8) might reflect relative importance of $\mathrm{Ca}-\mathrm{OH}$ and alkali- $\mathrm{OH}$ bonding. If so, it appears $\mathrm{Ca} /$ $\mathrm{P} \sim 5 / 3$ series with increasing $\mathrm{CaO}$ and $\mathrm{P}_{2} \mathrm{O}_{5}$ content, $\mathrm{Ca}-$ $\mathrm{OH}$ bonding becomes more important relative to $\mathrm{OH}$ groups bonded to alkali metals. In the $\mathrm{Ca} / \mathrm{P} \sim 1$ series of glasses, this trend is less evident.

\section{DISCUSSION}

\subsection{Solution Mechanism of Phosphorus in Anhydrous Peraluminous Glasses}

The mechanism of incorporation of $\mathrm{P}$ in peraluminous glasses is first detailed for the dry compositions. The spectroscopic data are interpreted to suggest that phosphorus is present in the two series of glasses studied primarily as $\mathrm{AlPO}_{4}$ species. There is also evidence for $\mathrm{P}-\mathrm{O}-\mathrm{Si}$ bonding thus suggesting cross-linking between the phosphate complexes and the aluminosilicate network. From Raman spectroscopic data, the presence of phosphate units with doublebonded oxygen can be ruled out (they should appear as peaks at $\geq 1320 \mathrm{~cm}^{-1}$, e.g., Kosinski et al., 1988, and no Raman intensity was observed in this spectral range).

The Al that participates in the formation of $\mathrm{AlPO}_{4}$ units may come from two distinct structural positions. One is where $\mathrm{Al}^{3+}$ is charge-balanced with alkalis and possibly Ca. In one case, this mechanism results in the formation of nonbridging oxygen as illustrated with the following schematic equations (for monovalent and divalent charge-balancing cations ):

$$
\begin{aligned}
& 2 \mathrm{M}^{+} \mathrm{AlSi}_{n} \mathrm{O}_{2 n+2}+\mathrm{P}_{2} \mathrm{O}_{5}=2 \mathrm{AlPO}_{4}+2 \mathrm{M}^{+} \mathrm{Si}_{n} \mathrm{O}_{2 n+3} \\
& \mathrm{M}^{2+} \mathrm{Al}_{2} \mathrm{Si}_{n} \mathrm{O}_{(2 n+4)}+\mathrm{P}_{2} \mathrm{O}_{5}=2 \mathrm{AlPO}_{4}+\mathrm{M}^{2+} \mathrm{Si}_{n} \mathrm{O}_{(2 n+1)}
\end{aligned}
$$

Toplis and Dingwell ( 1996 ) suggested an alternative mechanism to form $\mathrm{AlPO}_{4}$ complexes where one may envision exchange of alkalies (or alkaline earths) between chargebalanced $\mathrm{Al}^{3+}$ and phosphate complexes:

$$
\begin{gathered}
\mathrm{M}^{+} \mathrm{AlO}_{2}+\mathrm{P}_{2} \mathrm{O}_{5}=\mathrm{AlPO}_{4}+\mathrm{M}^{+} \mathrm{PO}_{3} \\
\mathrm{M}^{2+} \mathrm{Al}_{2} \mathrm{O}_{4}+2 \mathrm{P}_{2} \mathrm{O}_{5}=2 \mathrm{AlPO}_{4}+\mathrm{M}^{2-}\left(\mathrm{PO}_{3}\right)_{2}
\end{gathered}
$$

In the case illustrated by Eqns. 1 and 2, P solution would involve the production of network modifiers (alkalis and $\mathrm{Ca}$ ), resulting in depolymerization of the melt. This model would have a large influence on the framework structure, which is not observed in the Raman spectra. We, therefore, view this possibility as unlikely. An important implication of this observation is that $\mathrm{P}$ incorporation in these aluminosilicate glass systems has little influence on the aluminosilicate network.

Phosphate complexing according to the mechanisms la or $2 \mathrm{a}$, or both, does not affect the NBO/T of the aluminosilicate network. However, in this mechanism the $\mathrm{Al} /(\mathrm{Al}+\mathrm{Si})$ of the aluminosilicate must decrease as phosphorus is dissolved. This postulated decrease in $\mathrm{Al} /(\mathrm{Al}+\mathrm{Si})$ will result in an increase in frequency of the (Si.Al) $-\mathrm{O}^{\circ}$ stretch vibrations near 1000,1090 , and $1160 \mathrm{~cm}^{-1}$ in the P-free glasses (Seifert et al., 1982; Neuville and Mysen, 1996) as $P$ is dissolved. Such a frequency increase is not observed. Further, from a stoichiometric point of view, only metaphosphate $\left(\mathrm{PO}_{3}^{-}\right)$units can be formed without generating excess $\mathrm{Al}$ which might result in additional nonbridging oxygen in the melts. The frequency of $\mathrm{P}_{-} \mathrm{O}^{-}$stretching in $\mathrm{PO}_{3}^{-}$units in crystalline $\mathrm{NaPO}_{3}$ is near $1165 \mathrm{~cm}^{-1}$ (Nelson and Tallant, 1986). There is no evidence for such a band in the Raman spectra. The mechanisms proposed by Toplis and Dingwell (1996) and illustrated with expressions $1 \mathrm{a}$ and $2 \mathrm{a}$ are not, therefore, consistent with the data.

An alternative is a conceptually similar model with the phosphate complexes less polymerized than that of $\mathrm{PO}_{3}$. Such a model can be illustrated with the expressions:

$$
\begin{aligned}
8 \mathrm{M}^{+} \mathrm{AlO}_{2} & +3 \mathrm{P}_{2} \mathrm{O}_{5} \\
& =2 \mathrm{AlPO}_{4}+2 \mathrm{M}^{+} 4 \mathrm{P}_{2} \mathrm{O}_{7}+6 \mathrm{Al}^{3-} \text { (excess) }
\end{aligned}
$$


$3 \mathrm{M}^{+} \mathrm{AlO}_{2}+\mathrm{P}_{2} \mathrm{O}_{5}$

$$
=\mathrm{AlPO}_{4}+\mathrm{M}_{3}^{+} \mathrm{PO}_{4}+2 \mathrm{Al}^{3+}(\text { excess })
$$

where $\mathrm{Al}^{3+}$ (excess) represents $\mathrm{Al}^{3+}$ in excess of that for which alkali charge-compensation would be available. Analogous expressions could be written with divalent cations (e.g., alkaline earths).

Mechanism $1 \mathrm{~b}$ is unlikely because $\mathrm{P}-\mathrm{O}^{-}$stretching in pyrophosphate units results in Raman bands near $1020 \mathrm{~cm}^{-1}$ (Nelson and Tallant, 1985), which have not been observed in the spectra. Mechanism 1c (orthophosphate complexing) will be considered in more detail because there is a very, very weak band near $940 \mathrm{~cm}^{-1}$ in the nominally anhydrous samples. By using the Raman data from Mysen (1996) for the purpose of estimating relations between Raman intensity and $\mathrm{P}$ concentration, with the $\leq 0.5 \%$ of the intensity of the $940 \mathrm{~cm}^{-1}$ band relative to the strongest band in the high-frequency envelope of the anhydrous samples, this intensity would correspond to $\leq 0.5 \%$ of the total mount of dissolved $\mathrm{P}_{2} \mathrm{O}_{5}$ in the form of orthophosphate units. It would seem, therefore, that none of the mechanisms involving alkali or alkaline earth exchange between aluminate and phosphate are consistent with the Raman data for these glasses.

In the second possible case, $\mathrm{P}$ is structurally bonded with excess $\mathrm{Al}^{3+}$ present. This $\mathrm{Al}^{3+}$ may be linked either to $\mathrm{Si}$ - or Al-bearing $\mathrm{Q}^{3}$ species, themselves connected to the network. This mechanism is consistent with the phosphorus solubility data of Wolf and London (1994), for example. In that study, it was observed that there was a 1:1 correlation between $P$ solubility and $\mathrm{Al}$ content whenever the $\mathrm{P} / \mathrm{Al}=1$. Phosphorus incorporation in such glasses can then be described by the following homogeneous equilibrium:

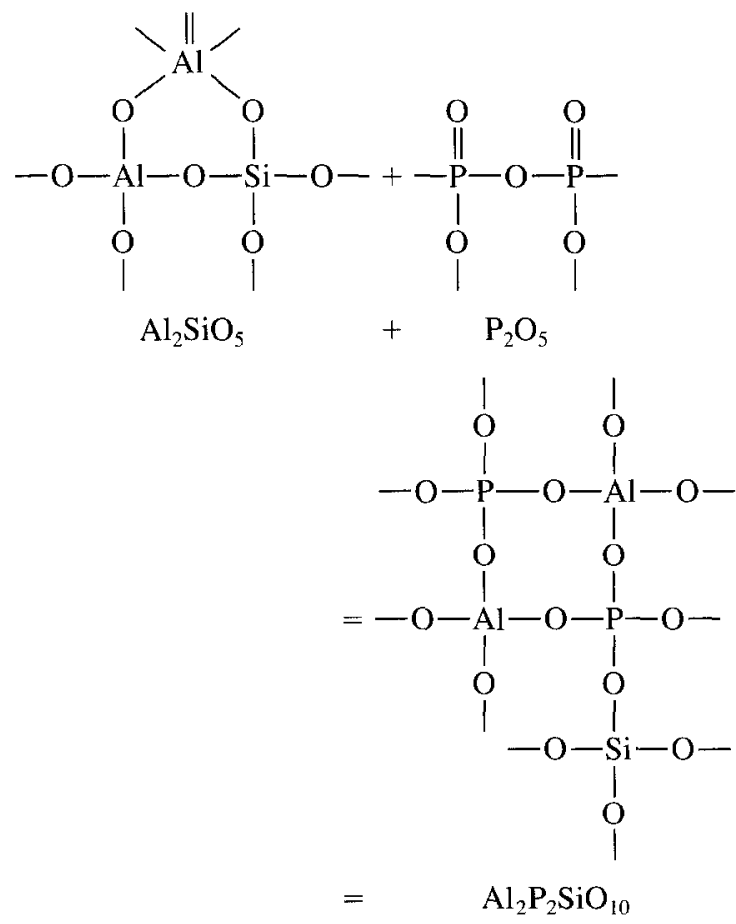

(3)
If some of the original excess $\mathrm{Al}^{3+}$ existed in a nonnetwork-forming structural position, ${ }^{8}$ the process involves an overall reduction of the NBO/T and the formation of $\mathrm{Q}^{4}$ species, i.e., polymerization. The $\mathrm{Q}^{4}$ silicate tetrahedra and charge-balanced $\mathrm{AlO}_{4}$ tetrahedra forming the network remain unaffected, implying that the structural roles of alkali and $\mathrm{Ca}$ do not need to be affected. The total amount of $\mathrm{P}$ present in our glasses can be incorporated completely with the above mechanism, because the amount of excess $\mathrm{Al}^{3+}$ present exceeds the amount of phosphorus dissolved. This solution mechanism is consistent with the P diffusion data for quite similar bulk compositions in the same system as reported by Wolf and London (1994). Wolf and London (1994) found that there was no absolute or relative change in $\mathrm{Na}$ and $\mathrm{K}$ concentration in the apatite diffusion aureole compared with the original melt, which is exactly what would be expected from the structural model of $\mathrm{P}$ solution proposed here. In other words, the compositions are so Alrich and peraluminous that there is no need to involve those $\mathrm{Al}^{3+}$ atoms charge-balanced by alkalis or $\mathrm{Ca}^{2+}$ and forming part of the network (see Table 1).

If, in fact, there is also interaction between $\mathrm{P}$ and chargebalanced $\mathrm{Al}^{3+}$, the structural scenario illustrated with Eqns. 1 and 2 requires consideration. Mechanisms $1 \mathrm{a}, \mathrm{b}, \mathrm{c}$ and $2 \mathrm{a}$ will not be considered further for the reasons discussed above. In scenarios 1 and 2, nonbridging oxygen will be generated. Relevant Raman bands reflecting increasing depolymerization of the structure as $\mathrm{P}$ is dissolved cannot be discerned in the spectra although the sensitivity of the spectra of these samples to such structural features is somewhat difficult to establish quantitatively. A very conservative estimate of the sensitivity might be derived in the following manner. The Raman cross-sections of $(\mathrm{Si}, \mathrm{Al})-\mathrm{O}^{-}$stretch vibrations is on the order of 1 order of magnitude greater than those of $(\mathrm{Si}, \mathrm{Al})-\mathrm{O}^{\circ}$ stretching vibrations in these systems (e.g., Mysen, 1995). Therefore, if, for example, a sample contained $5 \%$ of structural units containing nonbridging oxygen and $95 \%$ fully polymerized units, the Raman intensities from the depolymerized units should be about $50 \%$ of the maximum intensity of the high-frequency envelope. This would be easily observed but was not detected in the spectra. A conservative estimate of sensitivity to nonbridging oxygen from this discussion is, therefore, $5 \%$ of the total.

\subsection{The Role of $\mathrm{H}_{2} \mathrm{O}$ in P-Bearing Glasses}

The spectroscopic information on hydrous, P-free glasses is consistent with solution of water via association with alkalis or alkaline earths, possibly with $\mathrm{Al}$, and probably with Si. There is also molecular water in the glasses. This conclu-

\footnotetext{
${ }^{\$} \mathrm{Al}^{3+}$ without charge-balance in tetrahedral coordination has been suggested to form tri-clusters where $\mathrm{Al}^{3+}$ actually also has 4 oxygen ligands (Lacy, 1963). Recently, it has also been suggested that in peraluminous melts, $\mathrm{Al}^{3+}$ may reside in structural entities involving four-, five-, and six-fold coordination with oxygen (Sato et al., 1991; Poe et al., 1992). For the present purposes, it is not necessary to know the exact structural position of $\mathrm{Al}$ in peraluminous melts other than the fact that the $\mathrm{Al}$ is not a part of the aluminosilicate glass and melt network.
} 
sion is consistent with previously suggested models for $\mathrm{H}_{2} \mathrm{O}$ solution mechanisms in alumino-silicate melts and glasses (e.g., Mysen and Virgo, 1986b; Silver et al., 1990; Kohn et al., 1992; Holtz et al., 1996).

The Raman spectra of $\mathrm{H}_{2} \mathrm{O}$ - and P-bearing glasses differ from both the anhydrous, P-bearing and P-free anhydrous glasses in (1) the presence of a distinct Raman band near $940 \mathrm{~cm}^{-1}$ and (2) a considerably larger value of the area ratio, $A_{1120} /\left(A_{1120}+A_{1210}\right)$ (Fig. 10). The latter observation is consistent with greater relative abundance of $P$ bonded as $\mathrm{P}-\mathrm{O}-\mathrm{Al}$ relative to $\mathrm{P}-\mathrm{O}-\mathrm{Si}$ in hydrous relative to anhydrous P-bearing samples. The relative decline in abundance of Si$\mathrm{O}-\mathrm{P}$ bridges in hydrous samples may be due to replacement of the oxygen bridge with $\mathrm{OH}$ groups:<smiles>CO[Al](OC)OP1(OC)(O[CH2+]O)O[Al](OC)O[PH](OC)(OC)O[Si](OC)(OC)O1</smiles><smiles>CO[Al]1(OC)O[Al](OC)(O[Si](O)(OC)O[Si](O)(OC)OC)O[V](OC)(OC)O[V](OC)(OC)O1</smiles>

It is possible that the $\sim 940 \mathrm{~cm}^{-1}$ band observed in the Raman spectra of hydrous, P-bearing samples might then be assigned to $\mathrm{P}-\mathrm{OH}$ vibrations analogous to the $970 \mathrm{~cm}^{-1}$ that is assigned to $\mathrm{Si}-\mathrm{OH}$ stretching. Consequently, in this solution model of water into $\mathbf{P}$-bearing peraluminous glasses has the effect of isolating the $\mathrm{AlPO}_{4}$ complexes from the silicate network through the formation of $\mathrm{P}-\mathrm{OH}$ bonds. A consequence of this solution model for $\mathrm{P}$ in hydrous peraluminous glasses is that most likely the solubility of $\mathrm{H}_{2} \mathrm{O}$ in P-bearing melts would differ from that in the same melt without phosphorus. Such an effect was demonstrated experimentally by Wolf and London (1994).

\section{CONCLUDING REMARKS}

Raman spectra of peraluminous granitic glasses are consistent with Al-O-P bonding, perhaps in an $\mathrm{AlPO}_{4}$-type complex, being a principal solution mechanism of $P$. These complexes are linked with the silicate network over Si-O-P bridges. In hydrous systems, the $\mathrm{Si}-\mathrm{O}-\mathrm{P}$ bridges are broken and replaced with $\mathrm{OH}$-groups attached to $\mathrm{Si}-\mathrm{OH}$ and probably $\mathrm{P}-\mathrm{OH}$. Therefore, the water content of peraluminous aluminosilicate melts are likely to affect the solubility behavior of $\mathrm{P}$, and conversely, the solubility behavior of $\mathrm{H}_{2} \mathrm{O}$ is affected by $P$ in such melts.

Acknowledgments-A majority of this work was conducted while one of us (BOM) visited CNRS-CRSCM during the summer of 1994. The hospitality extended by CNRS is greatly appreciated. This work was partially supported by NSF grants EAR9218890 and EAR9614423 to BOM, by a grant from Centre National de la Recherce Scientifique through its Programme International de Cooperation Scientifique (PICS 192) and partially by the NSF-sponsored Center for High-Pressure Research (CHiPR). Critical reviews by M. Toplis, D. London, G. Morgan, and F. R. Ryerson improved the manuscript.

Editorial handling: D. B. Dingwell

\section{REFERENCES}

Aines R. D. and Rossman G. R. (1984) Water in minerals? A peak in the infrared. J. Geophys. Res. 89, 4059-4071.

Behrens H. (1995) Determination of water solubilities in high-viscosity melts: An experimental study on $\mathrm{NaAlSi}_{3} \mathrm{O}_{8}$ and $\mathrm{KAlSi} \mathrm{H}_{3} \mathrm{O}_{8}$ melts. Eur. J. Mineral. 7, 905-920.

Chakraborty I. N. and Condrate R. A. (1985) The vibrational spectra of glasses in the $\mathrm{Na}_{2} \mathrm{O}-\mathrm{SiO}_{2}-\mathrm{P}_{2} \mathrm{O}_{5}$ system with a $1: 1 \mathrm{SiO}_{2}: \mathrm{P}_{2} \mathrm{O}_{5}$ molar ratio. Phys. Chem. Glasses 26, 68-74.

Davidon W. C. (1966) Variable Metric Method for Minimization. Argonne Natl. Lab. ANL 5990.

Dingwell D. B., Knoche R., and Webb S. L. (1993) The effect of $\mathrm{P}_{2} \mathrm{O}_{5}$ on the viscosity of haplogranite liquids. Eur. $J$. Mineral. 5, $133-140$.

Dupree R., Holland D., and Mortuza M. G. (1988) The role of smal] amounts of $\mathrm{P}_{2} \mathrm{O}_{5}$ in the structure of alkali disilicate glasses. Phys. Chem. Glasses 29, 18-21.

Dupree R., Holland D., Mortuza J. A., Collins J. A., and Lockyer M. W. G. (1989) Magic angle spinning NMR of alkali phosphoalumino-silicate glasses. J. Non-Cryst. Solids 112, $111-119$.

Galeener F. L. (1982) Planar rings in glasses. Solid State Comm. 44, $1037-1040$.

Gan H. and Hess P.C. (1992) Phosphate speciation in potassium aluminosilicate glasses. Amer. Mineral. 77, 495-506.

Hamilton, W. C. (1965) Significance of the crystallographic R-factor. Acta Cryst. 18, 502-510.

Harrison T. M. and Watson E. B. (1984) The behaviour of apatite during crustal anatexis: Equilibrium and kinetic considerations. Geochim. Cosmochim. Acta 48, 1468-1477.

Holtz F., Behrens H., Dingwell D. B., and Johannes W. (1995) $\mathrm{H}_{2} \mathrm{O}$ solubility in haplogranitic melts: Compositional, pressure, and temperature dependence. Amer. Mineral. 80, 94-108.

Holtz F., Beny J.-M., Mysen B. O., and Pichavant M. (1996) Hightemperature Raman spectroscopy of silicate and aluminosilicate hydrous glasses: Implications for water speciation. Chem. Geol. 128, 25-39.

Kohn S. C., Dupree R., and Smith M. E. (1989) A nuclear magnetic resonance study of the structure of hydrous albite glasses. Geochim. Cosmochim. Acta 53, 2925-2935.

Kohn S. C., Dupree R., and Mortuza M. G. (1992) The interaction between water and aluminosilicate magma. Chem. Geol. 96, 399410 .

Kosinski S. G., Krol D. M., Duncan T. M., Douglass D. C., Mac- 
Chesney J. B., and Simpson J. R. (1988) Raman and NMR spectroscopy of $\mathrm{SiO}_{2}$ glasses co-doped with $\mathrm{Al}_{2} \mathrm{O}_{3}$ and $\mathrm{P}_{2} \mathrm{O}_{5}$. J. NonCryst. Solids 105, 45-52.

Kushiro I. (1975) On the nature of silicate melt and its significance in magma genesis: Regularities in the shift of the liquidus boundaries involving olivine, pyroxene, and silica minerals. Amer. J. Sci. 275, $411-431$

Lacy E. D. (1963) Aluminum in glasses and melts. Phys. Chem. Glasses 4, 234-238.

London D. (1987) Internal differentiation of rare element pegmatites: Effects of boron, phosphorus and fluorine. Geochim. Cosmochim. Acta 51, 403-420.

London D., Morgan G. B., VI, Babb H. A., and Loomis J. L. ( 1993) Behavior and effects of phosphorus in the system $\mathrm{Na}_{2} \mathrm{O}-\mathrm{K}_{2} \mathrm{O}$ $\mathrm{Al}_{2} \mathrm{O}_{3}-\mathrm{SiO}_{2}-\mathrm{P}_{2} \mathrm{O}_{5}-\mathrm{H}_{2} \mathrm{O}$ at $200 \mathrm{MPa}\left(\mathrm{H}_{2} \mathrm{O}\right)$. Contrib. Mineral. Petrol. 113, 450-465.

Long D. A. (1977) Raman Spectroscopy. McGraw-Hill.

Mammone J. F., Sharma S. K., and Nicol M. F. (1981) Ring structures in silica glass-A Raman spectroscopic investigation. EOS 62,425 .

Matson D. W., Sharma S., and Philpotts J. A. (1986) Raman spectra of some tectosilicates and glasses along the orthoclase-anorthite and nepheline-anorthite joins. Amer. Mineral. 71, 694-704.

McMillan P. F., Poe B. T., Stanton T. R., and Remmele R. L. (1993) A Raman spectroscopic study of H/D isotopically substituted hydrous aluminosilicate glasses. Phys. Chem. Minerals 19, 454-459.

Mysen B. O. (1992) Iron and phosphorus in calcium silicate quenched melts. Chem. Geol. 98, 175-202.

Mysen B. O. (1995) Structural behavior of $\mathrm{Al}^{3+}$ in silicate melts: In situ, high-temperature measurements as a function of bulk chemical composition. Geochim. Cosmochim. Acta 59, 455-474.

Mysen B. O. (1996) Phosphorus speciation changes across the glass transition in highly polymerized alkali silicate glasses and melts. Amer. Mineral. 81, 1531-1534.

Mysen B. O. and Frantz J. D. ( 1992) Raman spectroscopy of silicate melts at magmatic temperatures: $\mathrm{Na}_{2} \mathrm{O}-\mathrm{SiO}_{2}, \mathrm{~K}_{2} \mathrm{O}-\mathrm{SiO}_{2}$, and $\mathrm{Li}_{2} \mathrm{O}-\mathrm{SiO}_{2}$ binary compositions in the temperature range $25-$ $1475^{\circ} \mathrm{C}$. Chem. Geol. 96, 321-332.

Mysen B. O. and Frantz J. D. (1994) Structure of haplobasaltic liquids at magmatic temperatures: In situ, high-temperature study of melts on the join $\mathrm{Na}_{2} \mathrm{Si}_{2} \mathrm{O}_{5}-\mathrm{Na}_{2}\left(\mathrm{NaAl}_{2} \mathrm{O}_{5}\right.$. Geochim. Cosmochim. Acta 58, 1711-1733.

Mysen B. O. and Virgo D. (1986a) Volatiles in silicate melts at high pressure and temperature 2. Water in melts along the join $\mathrm{NaAlO}_{2}-\mathrm{SiO}_{2}$ and a comparison of solubility mechanisms of water and fluorine. Chem. Geol. 57, 333-358.

Mysen B. O. and Virgo D. (1986b) Volatiles in silicate melts at high pressure and temperature. 1. Interaction between $\mathrm{OH}$ groups and $\mathrm{Si}^{4+}, \mathrm{Al}^{3+}, \mathrm{Ca}^{2+}, \mathrm{Na}^{+}$and $\mathrm{H}^{+}$. Chem. Geol. 57, 303-331.

Mysen B. O., Virgo D., Harrison W. J., and Scarfe C. M. (1980) Solubility mechanisms of $\mathrm{H}_{2} \mathrm{O}$ in silicate melts at high pressures and temperatures: A Raman spectroscopic study. Amer. Mineral. $65,900-914$

Mysen B. O., Ryerson F. J., and Virgo D. ( 1981) The structural role of phosphorous in silicate melts. Amer. Mineral. 66, 106-117.

Mysen B. O., Finger L. W., Seifert F. A., and Virgo D. (1982) Curve-fitting of Raman spectra of amorphous materials. Amer. Mineral. 67, 686-696.

Nelson C. and Tallant D. R. (1984) Raman studies of sodium silicate glasses with low phosphate contents. Phys. Chem. Glasses 25, $31-39$.

Nelson C. and Tallant D. R. (1986) Raman studies of sodium phosphates with low silica contents. Phys. Chem. Glasses 26, 119-122.

Neuville D. R. and Mysen B. O. (1996) Role of aluminum in the silicate network: In situ, high-temperature study of glasses and melts on the join $\mathrm{SiO}_{2}-\mathrm{NaAlO}_{2}$. Geochim. Cosmochim. Acta 60 , $1727-1738$.

Pichavant M. (1987) Effects of B and $\mathrm{H}_{2} \mathrm{O}$ on liquidus phase relations in the haplogranite system. Amer. Mineral. 72, 1056-170.

Pichavant M., Montel J.-M., and Richard L. ( 1992) Apatite solubility in peraluminous liquids: Experimental data and an extension of the Harrison-Watson model. Geochim. Cosmochim. Acta 56, $3855-3861$.

Poe B. T., McMillan P. F., Cote B., Massiot D., and Coutoures J.-P. (1992) $\mathrm{SIO}_{2}-\mathrm{Al}_{2} \mathrm{O}_{3}$ liquids: In situ study by high-temperature ${ }^{27} \mathrm{Al}$ NMR spectroscopy and molecular dynamics simulations. $J$. Phys. Chem. 96, 8220-8224.

Remmele R., Stanton T., McMillan P. F., and Holloway J. R. (1986) Raman spectra of hydrous glasses along the quartz-albite join. $\operatorname{EOS~67,~} 1274$.

Revesz A. G. and Walrafen G. E. (1983) Structural interpretation of some of the Raman lines from vitreous silica. J. Non-Cryst. Solids 54, 323-355.

Richard L. R., Pichavant M., Clarke D. B., and Montel J.-M. (1992) Effects of temperature, composition, and $f \mathrm{O}_{2}$ on apatite solubility and phosphorus behaviour in peraluminous granitic melts. V. M Goldschmidt Conf., Reston, A-90. (abstr.)

Roux J., Holtz F., Lefevre A., and Schulze F. (1994) A reliable high-temperature setup for internally-heated pressure vessels: Application to silicate melt studies. Amer. Mineral. 79, 1145-1150

Ryerson F. J. and Hess P.C. (1980) The role of $\mathrm{P}_{2} \mathrm{O}_{5}$ in silicate melts. Geochim. Cosmochim. Acta 44, 611-624.

Sato R. K., McMillan P. F. Dennison P., and Dupree R. (1991) A structural investigation of high alumina glasses in the $\mathrm{CaO}-\mathrm{Al}_{2} \mathrm{O}_{3-}$ $\mathrm{SiO}_{2}$ system via Raman and magic angle spinning nuclear magnetic resonance spectroscopy. Phys. Chem. Glasses 32, 149-160.

Seifert F. A., Mysen B. O., and Virgo D. (1982) Three-dimensional network structure in the systems $\mathrm{SiO}_{2}-\mathrm{NaAlO}_{2}, \mathrm{SiO}_{2}-\mathrm{CaAl}_{2} \mathrm{O}_{4}$, and $\mathrm{SiO}_{2}-\mathrm{MgAl}_{2} \mathrm{O}_{4}$. Amer. Mineral. 67, 696-711.

Seifert F. A., Mysen B. O., and Virgo D. (1983) Raman study of densified vitreous silica. Phys. Chem. Glasses 24, 141-145.

Silver L. and Stolper E. (1989) Water in albitic glasses. J. Petrol. 30, $667-710$.

Silver L., Ihinger P. D., and Stolper E. ( 1990) The influence of bulk composition on the speciation of water in silicate glasses. Contrib. Mineral. Petrol. 104, 142-162.

Stolen R. H. and Walrafen G. E. (1976) Water and its relation to broken bond defects in fused silica. J. Chem. Phys. 64, 26232631.

Stolper E. ( 1982 ) The speciation of water in silicate melts. Geochim. Cosmochim. Acta 46, 2609-2620.

Toplis M. J. and Dingwell D. W. (1996) The variable influence of $\mathrm{P}_{2} \mathrm{O}_{5}$ on the viscosity of melts of differing alkali/aluminum ratio: Implications for the structural role of phosphorus insilicate melts Geochim. Cosmochim. Acta 60, 4107-4121.

Toplis M. J., Dingwell D. B., and Libourel G. (1994a) The effect of phosphorus on the iron redox ratio, viscosity, and density of an evolved ferro-basalt. Contrib. Mineral. Petrol. 117, 293-304.

Toplis M. J., Libourel G., and Carroll M. R. (1994b) The role of phosphorus in crystallization processes of basalt: an experimental study. Geochim. Cosmochim. Acta 58, 797-810.

Vielzeuf D. and Montel J. M. (1994) Partial melting of metagreywackes. Part I. Fluid-absent experiments and phase relationships. Contrib. Mineral. Petrol. 117, 375-393.

Visser W. and Koster Van Groos A. F. (1979) Effects of $\mathrm{P}_{2} \mathrm{O}_{5}$ and $\mathrm{TiO}_{2}$ on liquid-liquid equilibria in the system $\mathrm{K}_{2} \mathrm{O}-\mathrm{FeO}-\mathrm{Al}_{2} \mathrm{O}_{3}$ $\mathrm{SiO}_{2}$. Amer. J. Sci. 279, 970-988.

Wasserburg G. J. (1957) The effects of $\mathrm{H}_{2} \mathrm{O}$ in silicate systems. $J$. Geol. 65, 15-23.

Watson E. B. (1976) Two-liquid partition coefficients: experimental data and geochemical applications. Contrib. Mineral. Petrol. 56, $119-134$.

Watson E. B. and Capobianco C. J. (1981) Phosphorus and the rareearth elements in felsic magmas: an assessment of the role of apatite. Geochim. Cosmochim. Acta 45, 2349-2358.

Wolf M. B. and London D. ( 1994) Apatite dissolution into peraluminous granitic liquids: An experimental study of solubilities and mechanisms. Geochim. Cosmochim. Acta 58, 4127-4145.

Wyllie P. J. and Tuttle O.F. (1964) Experimental investigation of silicate systems containing two volatile components. III. The effects of $\mathrm{SO}_{3}, \mathrm{P}_{2} \mathrm{O}_{5}, \mathrm{HCl}$, and $\mathrm{Li}_{2} \mathrm{O}$ in addition to $\mathrm{H}_{2} \mathrm{O}$ on the melting temperatures of albite and granite. Amer. J. Sci. 262,930939. 